UIII norden

\title{
Critical metals in discarded electronics
}

Mapping recycling potentials from selected waste electronics in the Nordic region

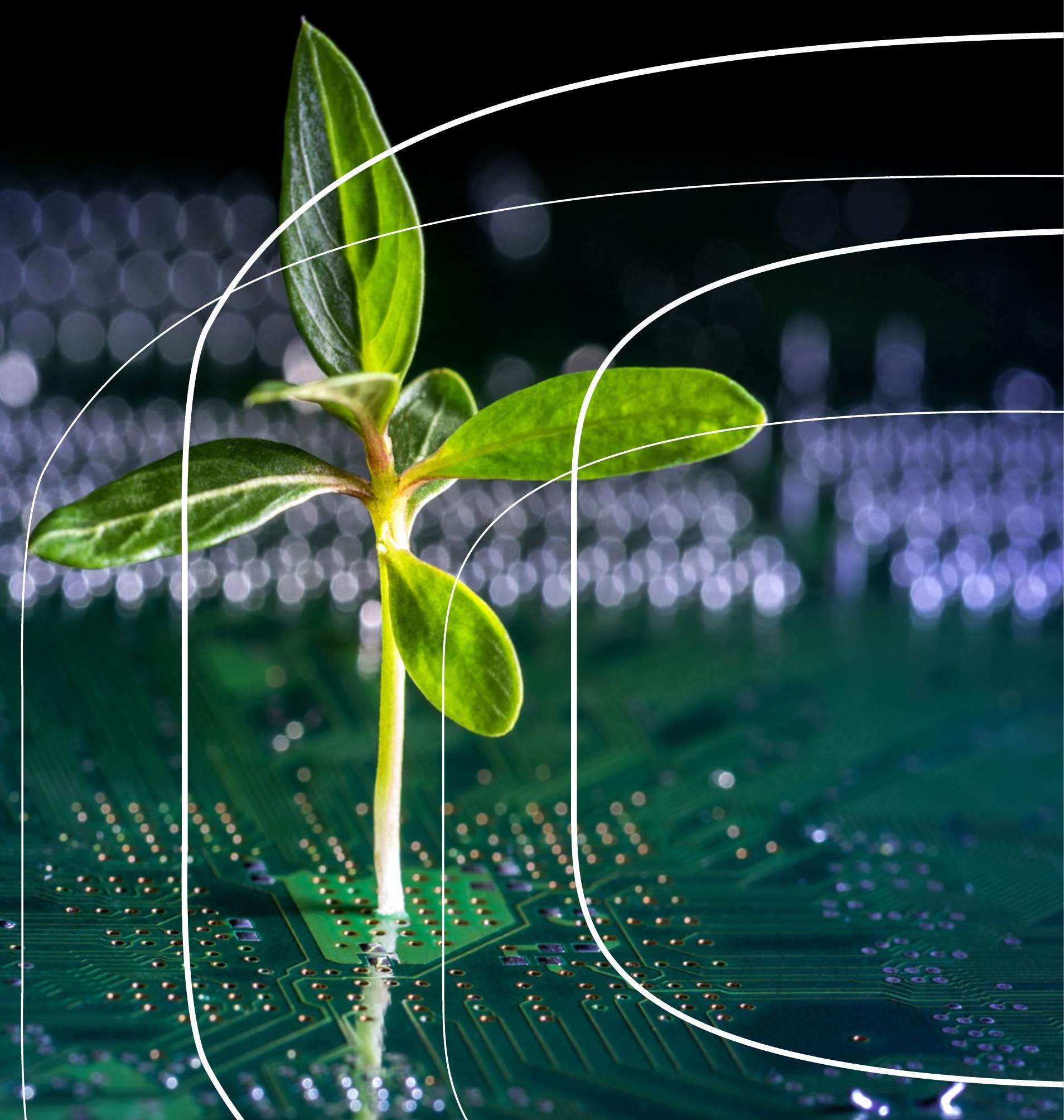







\section{Critical metals in discarded electronics}

Mapping recycling potentials from selected waste electronics in the Nordic region

Ioannis Bakas, Márton Herczeg, Eldbjørg Blikra Vea, Anna Fråne, Lena Youhanan and John Baxter 
Critical metals in discarded electronics

Mapping recycling potentials from selected waste electronics in the Nordic region

Ioannis Bakas, Márton Herczeg, Eldbjørg Blikra Vea, Anna Fråne, Lena Youhanan and John Baxter

ISBN 978-92-893-4569-9 (PRINT)

ISBN 978-92-893-4570-5 (PDF)

ISBN 978-92-893-4571-2 (EPUB)

http://dx.doi.org/10.6027/TN2016-526

TemaNord 2016:526

ISSN 0908-6692

(C) Nordic Council of Ministers 2016

Layout: Hanne Lebech

Cover photo: ImageSelect

Print: Rosendahls-Schultz Grafisk

Printed in Denmark

This publication has been published with financial support by the Nordic Council of Ministers. However, the contents of this publication do not necessarily reflect the views, policies or recommendations of the Nordic Council of Ministers.

www.norden.org/nordpub

\section{Nordic co-operation}

Nordic co-operation is one of the world's most extensive forms of regional collaboration, involving Denmark, Finland, Iceland, Norway, Sweden, and the Faroe Islands, Greenland, and Åland.

Nordic co-operation has firm traditions in politics, the economy, and culture. It plays an important role in European and international collaboration, and aims at creating a strong Nordic community in a strong Europe.

Nordic co-operation seeks to safeguard Nordic and regional interests and principles in the global community. Common Nordic values help the region solidify its position as one of the world's most innovative and competitive.

\section{Nordic Council of Ministers}

Ved Stranden 18

DK-1061 Copenhagen K

Phone (+45) 33960200

\section{www.norden.org}




\section{Contents}

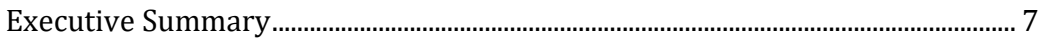

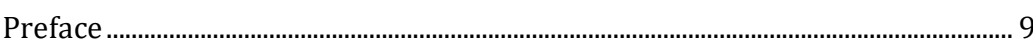

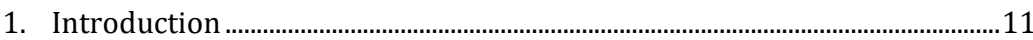

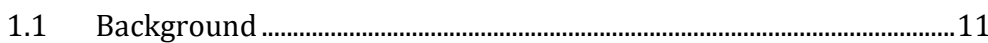

1.2 Selection of critical metals .......................................................................12

1.3 Selection of consumer electronics...........................................................12

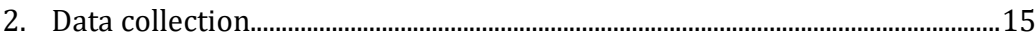

2.1 Data on waste generation.........................................................................15

2.2 Data on critical metal content of the selected products ......................18

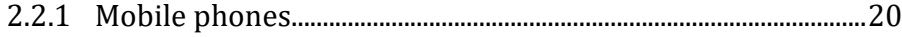

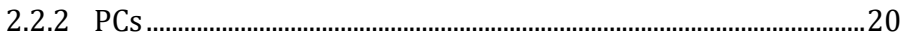

2.2.3 Flat screens and TV monitors......................................................21

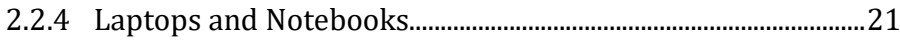

2.2.5 Rechargeable batteries.....................................................................21

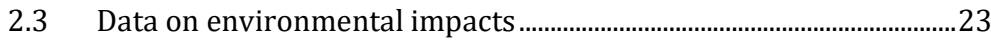

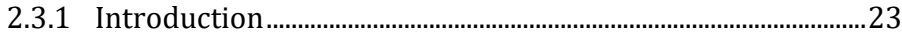

2.3.2 Data for recycled critical metals .................................................24

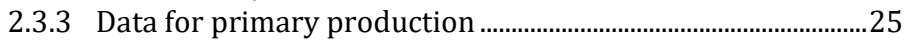

2.3.4 Data uncertainty ..........................................................................26

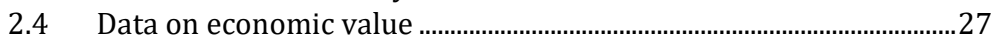

$2.5 \quad$ Issues around data credibility..................................................................

3. Critical metals in the Nordic WEEE .....................................................................33

3.1 Critical metals quantities in Nordic WEEE...........................................33

3.2 Discussion on environmental impacts .....................................................39

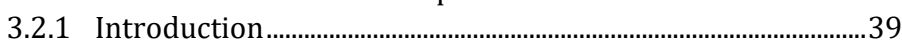

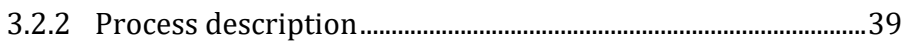

3.2.3 Metals recovery and environmental impacts .............................39

3.2.4 Potential for environmental benefits from critical metals recovery..

3.2.5 Discussion and conclusions.................................................................. 43

3.3 Discussion on economic consequences...................................................4

4. Proposals for a Nordic region strategy …….....................................................47

4.1 Proposals for improved waste management.........................................4 47

4.1.1 Policy recommendations.................................................................48

4.2 The Nordic region's role in global critical metals discussions .........49

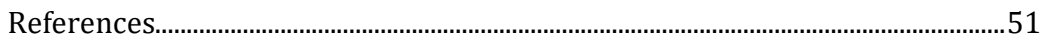

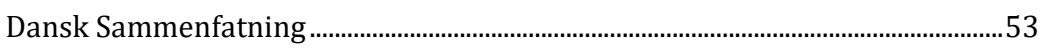





\section{Executive Summary}

Metals are characterised as critical when their supply rates are low compared with an increasing demand. Other aspects of this "criticality" include the metals' low dispersity around the world, low recycling rates and substitution potential as well as their importance for specific applications such as military equipment and hi-tech products.

Critical metals are widely used in electronics and when these products are discarded, the metals take part in the WEEE management systems of each country. However, the policy focus for WEEE recycling has traditionally been the recycled quantities, so the management systems organise themselves in order to maximise recovered quantities, thus overlooking materials' arisings in small quantities but with a potentially high economic and environmental value.

This project attempts to investigate the waste fate of 11 critical metals, present in five selected electronic product groups, as the table below demonstrates.

\begin{tabular}{|c|c|c|c|c|c|}
\hline Critical Metal & $\begin{array}{l}\text { Mobile } \\
\text { phones }\end{array}$ & PCs & $\begin{array}{c}\text { Flat screen } \\
\text { TVs }\end{array}$ & $\begin{array}{l}\text { Laptops and } \\
\text { notebooks }\end{array}$ & $\begin{array}{c}\text { Rechargeable } \\
\text { batteries }\end{array}$ \\
\hline Cobalt, Co* & & & + & & + \\
\hline Indium, In & + & + & + & + & + \\
\hline Lithium, Li* & & & + & & + \\
\hline Silver, Ag & + & + & + & + & + \\
\hline Tantalum, Ta & + & & + & + & \\
\hline Tungsten, W & + & + & $(+)$ & & \\
\hline Gold, Au & + & + & + & + & \\
\hline Beryllium, Be & + & + & & + & \\
\hline Gallium, Ga & + & + & + & + & \\
\hline Palladium, Pd & + & + & + & + & \\
\hline Ruthenium, Ru & & + & + & + & \\
\hline
\end{tabular}

In order to assess the recycling potential of these metals, the waste arisings of each of the selected groups is combined with information on their critical metal content for each of the Nordic countries. The waste quantities are estimated through sales data multiplied with the products' average life spans, while the metal content is extracted through a review of the latest relevant literature. When the recycling potential is estimated, data available in literature are used for calculating the environmental and 
economic benefits from recycling these metals, compared with extracting them from the ground. Life cycle data are used for estimating environmental impacts from recycling operations (direct emissions) and for raw material extraction processes (avoided emissions). The economic value of recovered metals is assumed equal to raw metals, as the recycling does not lead to any loss of quality for the critical metals.

The results of this exercise are revealing regarding the very significant potential hidden in discarded electronic equipment in the Nordic region. Regarding waste quantities, Cobalt and Lithium display the highest numbers due to their high presence in batteries, followed by gold and silver. The environmental and economic benefits are dominated by the presence of gold which is assigned by far the highest savings. The global warming potential savings from recycling all critical metals in the selected products in all Nordic countries are approximately 500,000 tonnes of $\mathrm{CO}_{2}$-eq annually for the period 2015-2020. The economic value of the metals in the selected waste products reach 1.6 billion EUR, almost exclusively due to the high value and quantity of gold.

Since there is a great economic and environmental potential to harness through increased recycling of critical metals, action needs to be taken by the Nordic countries. Policy recommendations might include:

- Incentives for increasing collection of discarded products, rich in critical metals.

- Emphasising the qualitative aspects of recycling and focus less on quantities alone.

- Standardising and targeting recycling of the critical metals themselves. 


\section{Preface}

The circular economy has become a buzz word within the global environmental policy debate during the past years. The concept, it is argued, can bring about economic as well as environmental benefits to our societies by managing our waste streams for efficiently. With this reports, Nordic Council of Ministers' Working Group on Environment and Economy (MEG) initiates an analysis which will focus on waste streams of critical metals and policy instruments for efficient management of the of these resources. We believe that this analysis is important and will become even more important in the future, since the use of products that require these materials are projected to increase even further the next coming decades. By commissioning this analysis, we also contribute to the EU circular economy strategy which among other waste streams also target critical raw materials.

This project will be followed by another where the focus on waste streams including their economic and environmental potential will shift to policy instruments to bring about more cost efficient use of these resources. Please visit our web page to follow this and other future projects, http://www.norden.org/meg.

A group of consultants led by Copenhagen Resource Institute was chosen to write the report. The group also includes IVL Swedish Environmental Research Institute and Østfoldforskning from Norway. The authors of the report are responsible for the content as well as the recommendations, which do not necessarily reflect the views and positions of the governments in the Nordic countries.

May 2016

\section{Fredrik Granath}

Chairman of the Working Group

on Environment and Economy

under the Nordic Council of Ministers. 



\section{Introduction}

\section{$1.1 \quad$ Background}

The sustainable management of rare earth metals and metals characterised by critical availability and supply has been the subject of intense debate in recent years. Looking forward, these metals are of strategic importance for a number of applications including military equipment, renewable energy technologies and consumer electronics, and suffer from technical, economic or geopolitical scarcity. The scarcity of the metals and their currently rather low (or non-existent) recycling rates and limited substitution potential has triggered discussions on ways to secure a supply of these metals through circular economy provisions such as the recycling of Waste from Electronic and Electrical Equipment (WEEE).

To date, recycling of WEEE has mainly focused on extracting highvolume metals: materials such as steel, aluminium, copper, glass and plastics. However, diverse EEE products contain significant amounts of critical metals and rare earth metals. Expanding the focus of recycling to include the recovery of critical and rare earth metals could potentially lead to substantial benefits. These include reducing environmental degradation from primary production, and direct access for Nordic-based companies to valuable materials for use in various technological applications. Few of these materials are directly available from primary sources in the Nordic region today, and manufacturing of EE appliances and reprocessing of materials into new products are mostly done in other parts of the world, often under quite low working standards.

This is thus a very interesting case for discussing the Nordic region's strategic role in developing sustainable resource management in a global circular economy with a potential to boost recycling of these materials in the Nordic countries. 


\subsection{Selection of critical metals}

There is no universally accepted definition for critical metals in the international literature, in spite of various efforts by international bodies such as the UN. ${ }^{1} \mathrm{~A}$ variety of definitions exist addressing the scarcity of some raw material, including, rare earth metals, rare metals, each with a different set of selection criteria.

This report focuses on critical metals. The criticality of these metals reflects their importance in key sectors of the economy and their availability. Seeking an appropriate definition for selecting critical metals, a good starting point is the relatively recent initiative undertaken by the EU on critical raw materials. ${ }^{2}$ This initiative defines a list of critical raw materials from a European perspective.

In general, a definition of critical metals should include aspects such as:

- Supply risks, denoting the concentration of the metal in a few countries, the physical and temporal scarcity.

- Demand growth, denoting the prospects for increase in global demand.

- Recycling restrictions, denoting the limitations in recycling of the metal.

Based on these considerations and the methodology developed in Bakas et al., 2014, a list of critical metals used in electronics can be compiled (see Table 1).

\subsection{Selection of consumer electronics}

The focus of this study lies with consumer electronics and their waste (WEEE). WEEE is selected as it is rich in critical metals. However, it is impossible to estimate the quantity of critical metals in the entire WEEE stream, as it is composed of many diverse appliances. The focus of this study is on consumer electronics, so a set of selected product groups was identified to be used as a proxy for estimates and conclusions that could represent the entire WEEE stream.

The criteria for the selection of the product groups are (inspired by Bakas et al., 2014):

\footnotetext{
${ }^{1}$ http://www.unep.fr/shared/publications/pdf/DTIx1202xPA-Critical\%20Metals\%20and\%20their\% 20Recycling\%20Potential.pdf

2 http://ec.europa.eu/growth/sectors/raw-materials/specific-interest/critical/index_en.htm
} 
- Significant quantities of the selected critical metals should be present in the product groups.

- The selected product groups should represent a significant economic activity within the consumer electronics market in the Nordic region.

- Data should be available regarding the critical metals' content in the selected product groups.

Based on these and the authors' own expert judgement, the selected product groups are: ${ }^{3}$

- Mobile phones

- PCs

- Flat screen TVs

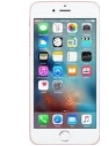

- Laptops/notebooks
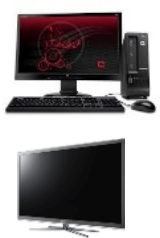

- Rechargeable batteries
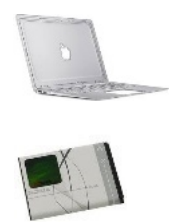

Table 2: Use of critical metals in selected product groups

\begin{tabular}{|c|c|c|c|c|c|}
\hline Critical Metal & Mobile phones & PCs & Flat screen TVs & $\begin{array}{l}\text { Laptops and } \\
\text { notebooks }\end{array}$ & $\begin{array}{c}\text { Rechargeable } \\
\text { batteries }\end{array}$ \\
\hline Cobalt, Co* & & & + & & + \\
\hline Indium, In & + & + & + & + & + \\
\hline Lithium, Li* & & & + & & + \\
\hline Silver, Ag & + & + & + & + & + \\
\hline Tantalum, Ta & + & & + & + & \\
\hline Tungsten, W & + & + & $(+)$ & & \\
\hline Gold, Au & + & + & + & + & \\
\hline Beryllium, Be & + & + & & + & \\
\hline Gallium, Ga & + & + & + & + & \\
\hline Germanium, Ge & + & + & & + & \\
\hline Palladium, Pd & + & + & + & + & \\
\hline Ruthenium, Ru & & + & + & + & \\
\hline
\end{tabular}

Source: *Cobalt and Lithium are used in mobile phones and laptops/notebooks in their batteries, but since batteries are examined separately, the presence of these metals in portable devices is ignored (Bakas et al., 2014).

${ }^{3}$ Sources for the images are apple.com, amazon.com, samsung.com 



\section{Data collection}

\subsection{Data on waste generation}

Waste data can be found in national or international sources: national statistical offices or environmental protection agencies (EPAs) and Eurostat. However, waste data is collected in a more aggregated level than the selected product groups: data from these sources corresponds to the WEEE categories as defined in European legislation (EC, 2012). Also waste data often refer to collected amounts and not generated amounts. The purpose of the project is not to investigate the efficiency of waste collection systems, but to estimate the amount of critical metals in waste available for collection and processing. As such, waste generation data should be used and not data on waste collected.

To estimate the quantities of waste generated within these product groups, sales data was combined with data on product life spans to generate approximations for the amount of waste generated. This approach has the disadvantage of relatively higher uncertainty (brought on, for example, by using average life spans of products). On the other hand, the estimated waste quantities refer to all waste potentially available for collection.

Sales data for the selected product groups are available through the UN comtrade database (UN, 2015). This database collects trade data: exports and imports of products. None of these product groups are domestically produced in the Nordic region - verified by examining the Eurostat's prodcom database (Eurostat, 2015a), which shows no domestic production in the selected countries for the period in question. ${ }^{4}$ As such, the net of import and export can be used to approximate domestic consumption data in each of the Nordic countries examined (DK, FI, NO, SE). ${ }^{5}$

Data on average life spans within the product groups have been extracted from an older Nordic report (TemaNord, 2009). The average life spans are rounded to the nearest year.

4 Prodcom also includes trade data but the data availability is lower than the UN database so it was not further selected as a source.

${ }^{5}$ IS has been excluded due to low data availability. 
Table 3: Average life spans assumed for the selected product groups

\begin{tabular}{lcccc} 
Product & Mobile phones & Flatscreen TVs & Laptops and notebooks & PCs \\
\hline Average life span (years) & 3 & 6 & 5 & 5 \\
\hline
\end{tabular}

Combining the sales data with the average product life spans (Table 2) derives the potential generation of waste within the product groups for the period 2015-2020. The average life spans for mobile phones, laptops and notebooks and PCs, are shorter than the period under examination. To create a full waste generation time series for these products, it is necessary to extrapolate the data from preceding years. Extrapolated data is indicated in italic script (Table 3).

Table 4: Estimated waste quantities (tonnes) generated in the Nordic countries for 2015-2020. Italic numbers are projection estimates from the previous years' trends

\begin{tabular}{|c|c|c|c|c|c|c|c|}
\hline \multirow[t]{2}{*}{ Country } & \multirow[t]{2}{*}{ Product group } & \multicolumn{6}{|c|}{ Year } \\
\hline & & 2015 & 2016 & 2017 & 2018 & 2019 & 2020 \\
\hline \multirow[t]{4}{*}{ DK } & Mobile phones & 989 & 691 & 556 & 496 & 443 & 396 \\
\hline & Flatscreen TVs & 13,205 & 8,211 & 8,248 & 7,567 & 5,970 & 5,986 \\
\hline & Laptops and notebooks & 2,782 & 3,291 & 3,243 & 2,888 & 2,579 & 2,487 \\
\hline & PCs & 6,406 & 5,977 & 4,519 & 4,990 & 3,937 & 3,582 \\
\hline \multirow[t]{4}{*}{$\mathrm{FI}$} & Mobile phones & $714^{\mathrm{A}}$ & 715 & 716 & 718 & 719 & 721 \\
\hline & Flatscreen TVs & 7,904 & 7,918 & 7,328 & 7,219 & 6,103 & 5,990 \\
\hline & Laptops and notebooks & 2,795 & 2,450 & 1,992 & 1,835 & 2,118 & 2,044 \\
\hline & PCs & 7,116 & 7,398 & 5,805 & 7,423 & 9,319 & 10,179 \\
\hline \multirow[t]{4}{*}{ NO } & Mobile phones & 1,081 & 1,135 & 887 & 833 & 781 & 733 \\
\hline & Flatscreen TVs & 12,362 & 11,485 & 9,696 & 8,681 & 7,285 & 6,392 \\
\hline & Laptops and notebooks & 3,320 & 3,628 & 3,748 & 3,412 & 3,272 & 3,267 \\
\hline & PCs & $4,125^{\mathrm{B}}$ & 3,997 & 5,357 & 6,086 & 5,594 & 5,993 \\
\hline \multirow[t]{4}{*}{ SE } & Mobile phones & 1,235 & 1,163 & 1,320 & 1,362 & 1,406 & 1,451 \\
\hline & Flatscreen TVs & 16,704 & 9,963 & 10,254 & 10,985 & 7,321 & 11,622 \\
\hline & Laptops and notebooks & 4,389 & 4,801 & 5,034 & 4,470 & 4,547 & 4,625 \\
\hline & PCs & 15,531 & 12,436 & 9,202 & 8,347 & 9,832 & 9,255 \\
\hline
\end{tabular}

Source: AThis cell is estimated by using sales data from 2012, when still some domestic production was taking place. Since the domestic production data is not available, the waste estimated through import-export data is wrong. So, for this cell the trend of 2016-2017 waste data is used.

${ }^{B} T h e$ estimated quantities for 2014 and 2015 through the sales data were too low (about one third of the adjacent years). Therefore, it has been replaced by the average of the waste data for 2013 and 2016 
This approach covers all selected product groups except batteries (where no data was available). For batteries, Eurostat's data on "Batteries and accumulators and waste batteries" is used instead. The extracted data included only waste in the relevant countries generated by households, as the scope of this project refers to rechargeable batteries from consumer electronics and not, for instance, industrial or vehicle batteries. ${ }^{6}$ As the latest data year is 2012, the household battery wastes were projected to 2020 according to each country's GDP projection estimates (Table 4). The household battery waste estimates were further broken down into specific types in order to select the rechargeable battery types only. ${ }^{7}$ Four battery types were selected, Li-ion, $\mathrm{Ni}-\mathrm{Cd}, \mathrm{Ni}-\mathrm{MH}$ and $\mathrm{Pb}$-acid, as these correspond to rechargeable batteries found in consumer electronics.

\begin{tabular}{|c|c|c|c|c|c|c|c|}
\hline \multicolumn{2}{|c|}{ Batteries } & \multirow{2}{*}{$\begin{array}{r}2015 \\
931\end{array}$} & \multirow{2}{*}{$\begin{array}{r}2016 \\
949\end{array}$} & \multirow{2}{*}{$\begin{array}{r}2017 \\
966\end{array}$} & \multirow{2}{*}{$\begin{array}{r}2018 \\
984\end{array}$} & \multirow{2}{*}{$\begin{array}{r}2019 \\
1,001\end{array}$} & \multirow{2}{*}{$\begin{array}{r}2020 \\
1,019\end{array}$} \\
\hline DK & Li-ion & & & & & & \\
\hline & Pb-acid & 201 & 205 & 209 & 213 & 217 & 220 \\
\hline & $\mathrm{Ni}-\mathrm{Cd}$ & 50 & 51 & 52 & 53 & 54 & 55 \\
\hline & $\mathrm{Ni}-\mathrm{MH}$ & 75 & 77 & 78 & 80 & 81 & 83 \\
\hline \multirow[t]{4}{*}{$\mathrm{FI}$} & Li-ion & 707 & 713 & 721 & 729 & 737 & 745 \\
\hline & $\mathrm{Pb}$-acid & 153 & 154 & 156 & 158 & 159 & 161 \\
\hline & $\mathrm{Ni}-\mathrm{Cd}$ & 38 & 39 & 39 & 39 & 40 & 40 \\
\hline & $\mathrm{Ni}-\mathrm{MH}$ & 57 & 58 & 58 & 59 & 60 & 60 \\
\hline \multirow[t]{4}{*}{ NO } & Li-ion & 1,169 & 1,181 & 1,205 & 1,228 & 1,252 & 1,276 \\
\hline & Pb-acid & 253 & 255 & 260 & 266 & 271 & 276 \\
\hline & $\mathrm{Ni}-\mathrm{Cd}$ & 63 & 64 & 65 & 66 & 68 & 69 \\
\hline & $\mathrm{Ni}-\mathrm{MH}$ & 95 & 96 & 98 & 100 & 102 & 103 \\
\hline \multirow[t]{4}{*}{ SE } & Li-ion & 2,469 & 2,538 & 2,609 & 2,682 & 2,758 & 2,835 \\
\hline & Pb-acid & 534 & 549 & 564 & 580 & 596 & 613 \\
\hline & $\mathrm{Ni}-\mathrm{Cd}$ & 133 & 137 & 141 & 145 & 149 & 153 \\
\hline & $\mathrm{Ni}-\mathrm{MH}$ & 200 & 206 & 212 & 217 & 224 & 230 \\
\hline
\end{tabular}

${ }^{6}$ Data was missing from Norway, and it was estimated through battery wastes from all sources by assuming the household part to be identical to the average household part in total waste of the other Nordic countries. ${ }^{7}$ The breakdown was done according to a study of the battery university (BatteryUniversity, 2009). 


\subsection{Data on critical metal content of the selected products}

Sources of information that could be used to estimate the average content of the twelve critical metals in the product groups were identified via a literature search. This information was crucial to calculate an estimation of the total amount of critical metals present in the product groups wasted in the Nordics.

The focus for the literature search was primarily academic literature, and scientific articles. References were identified using keyword searches on critical metals, and the identified product groups. The search also sought project reports on critical metals. The rapidly changing characteristics and features of electronic equipment, and therefore possibly also the content of the critical metals, demand that references were contemporary, typically publishing within the last five years. Many of the identified references included valuable information about several critical metals in the product groups. This is why some references appear several times. Two references, Cuchiella et al. (2015) and Buchert et al. (2012), proved to be particularly useful.

There are numerous publications that detail the critical metal content of different kinds of electric and electronic equipment. However, the differences in reported values across these publications indicate that the information should only be used to estimate the magnitude of the amount of critical metals present in the product groups. The differences in reported values is a result of the diversity of products in each product group, and of how the content is measured (experimentally or theoretically) (Chancerel et al. 2013). As such, the content of critical metals in each product group used in this report should be seen as indicative.

Information on potential content of certain critical metals was scarcer for some product groups than for others. This might be explained by:

- The product group does not contain certain critical metals, which of course causes a data gap.

- Lack of documented data of critical metal content in general.

All data gaps investigated to identify the most probable explanation. It is thus important to emphasise that this evaluation is qualitative and based on the literature search. It should not be regarded as definitive.

To accommodate the differing values identified in from different sources, the content of critical metals in the products groups are 
presented here as ranges. The ranges consist of the minimum and maximum values found in the literature sources. For some product groups and critical metals, only one source was found. In these cases, this single value is presented. The maximum number of references for the content of a given critical metal is four. This solution avoids giving the impression that the data is more definite than it is, and also accounts for the variability of weights among items within the same product group.

The references presented the content of critical metals in different units: as a percent of an items weight; or in grams per unit. In some cases, estimated product weights were included, while in others such information was absent. To use the identified data, an average weight for an item each product group was required. This can be found in either trade data or literature. However, as the weights presented in literature varied noticeably, it was decided to use trade data. Specifically, the year 2014 was used as it was the most recent data point and had trade data for all product groups except rechargeable batteries. This was motivated by the convenience of having a single source for the weight of the product groups, and because the weights might differ from year to year, and from unit to unit within the same product group.

The results from the literature search are presented in the following tables. The data presented is used in all calculations throughout the project. The grey, purple and red areas represent information gaps:

- Grey areas indicate that the metal is likely not present in the product group.

- Purple areas indicate that the reason for the information gap is unknown.

- Red areas indicate that no quantative information was found in literature, but that the product group could contain the metal. 


\subsubsection{Mobile phones}

The average weight of a mobile phone is assumed to $0.29 \mathrm{~kg}$ per unit according to trade data for 2014. The data is valid for smart phones.

Table 5: Assumed content of critical metals in mobile phones

\begin{tabular}{|c|c|c|c|}
\hline Critical Metal & Average content (weight \%) & Low range & High range \\
\hline Cobalt, Co & $2.172 \%$ & & \\
\hline \multicolumn{4}{|l|}{ Indium, In } \\
\hline \multicolumn{4}{|l|}{ Lithium, Li } \\
\hline Silver, Ag & $0.090 \%$ & $0.084 \%$ & $0.105 \%$ \\
\hline \multicolumn{4}{|l|}{ Tantalum, Ta } \\
\hline \multicolumn{4}{|l|}{ Tungsten, W } \\
\hline Gold, Au & $0.009 \%$ & $0.083 \%$ & $0.010 \%$ \\
\hline Beryllium, Be & $0.001 \%$ & & \\
\hline \multicolumn{4}{|l|}{ Gallium, Ga } \\
\hline \multicolumn{4}{|l|}{ Germanium, Ge } \\
\hline Palladium, Pd & $0.004 \%$ & $0.003 \%$ & $0.005 \%$ \\
\hline Ruthenium, Ru & & & \\
\hline
\end{tabular}

\subsubsection{PCs}

The average weight of a PC is assumed to $7.13 \mathrm{~kg}$ per unit according to trade data for 2014.

Table 6: Assumed content of critical metals in PCs

\begin{tabular}{|c|c|c|c|}
\hline Critical Metal & Average content (weight \%) & Low range & High range \\
\hline Cobalt, Co & $0.0157 \%$ & & \\
\hline Indium, In & $0.00080 \%$ & $0.00055 \%$ & $0.00111 \%$ \\
\hline \multicolumn{4}{|l|}{ Lithium, Li } \\
\hline Silver, Ag & $0.08945 \%$ & $0.01890 \%$ & $0.16000 \%$ \\
\hline \multicolumn{4}{|l|}{ Tantalum, Ta } \\
\hline Tungsten, W & $0.00888 \%$ & & \\
\hline Gold, Au & $0.13000 \%$ & & \\
\hline \multicolumn{4}{|l|}{ Beryllium, Be } \\
\hline Gallium, Ga & $0.00004 \%$ & $0.00004 \%$ & $0.00005 \%$ \\
\hline \multicolumn{4}{|l|}{ Germanium, Ge } \\
\hline Palladium, Pd & $0.00056 \%$ & & \\
\hline Ruthenium, Ru & $0.00010 \%$ & & \\
\hline
\end{tabular}




\subsubsection{Flat screens and TV monitors}

The average weight of a flat screen or TV monitor is assumed to $6.92 \mathrm{~kg}$ per unit according to trade data for 2014.

\begin{tabular}{|c|c|c|c|}
\hline Critical Metal & Average content (weight \%) & Low range & High range \\
\hline \multicolumn{4}{|l|}{ Cobalt, Co } \\
\hline Indium, In & $0.00132 \%$ & $0.00004 \%$ & $0.00367 \%$ \\
\hline \multicolumn{4}{|l|}{ Lithium, Li } \\
\hline Silver, Ag & $0.00744 \%$ & $0.00650 \%$ & $0.00831 \%$ \\
\hline \multicolumn{4}{|l|}{ Tantalum, Ta } \\
\hline Tungsten, W & $0.00915 \%$ & & \\
\hline Gold, Au & $0.00233 \%$ & $0.00159 \%$ & $0.00289 \%$ \\
\hline \multicolumn{4}{|l|}{ Beryllium, Be } \\
\hline Gallium, Ga & $0.00006 \%$ & $0.00004 \%$ & $0.00007 \%$ \\
\hline \multicolumn{4}{|l|}{ Germanium, Ge } \\
\hline Palladium, Pd & $0.00061 \%$ & $0.00058 \%$ & $0.00064 \%$ \\
\hline Ruthenium, Ru & & & \\
\hline
\end{tabular}

\subsubsection{Laptops and Notebooks}

The average weight of a notebook/laptop is assumed to $2.68 \mathrm{~kg}$ per unit according to trade data for 2014.

Table 8: Assumed content of critical metals in notebooks/laptops

\begin{tabular}{|c|c|c|c|}
\hline Critical Metal & Average content (weight \%) & Low range & High range \\
\hline Cobalt, Co & $0.0024 \%$ & & \\
\hline Indium, In & $0.0015 \%$ & $0.0015 \%$ & $0.0015 \%$ \\
\hline \multicolumn{4}{|l|}{ Lithium, Li } \\
\hline Silver, Ag & $0.0128 \%$ & $0.0093 \%$ & $0.0163 \%$ \\
\hline Tantalum, Ta & $0.0634 \%$ & & \\
\hline \multicolumn{4}{|l|}{ Tungsten, W } \\
\hline Gold, $\mathrm{Au}$ & $0.0060 \%$ & $0.0039 \%$ & $0.0082 \%$ \\
\hline \multicolumn{4}{|l|}{ Beryllium, Be } \\
\hline Gallium, Ga & $0.0597 \%$ & & \\
\hline \multicolumn{4}{|l|}{ Germanium, Ge } \\
\hline Palladium, Pd & $0.0015 \%$ & $0.0015 \%$ & $0.0015 \%$ \\
\hline Ruthenium, Ru & & & \\
\hline
\end{tabular}

\subsubsection{Rechargeable batteries}

Four different types of batteries were chosen for this study: Lead acid, Nickel-Cadmium, Nickel-metal-hydride and lithium-ion batteries. The content of critical metals in lead acid batteries is unknown. 


\section{Nickel-Cadmium batteries}

The average weight of a rechargeable Nickel-Cadmium battery is assumed to $0.26 \mathrm{~kg}$ per unit based on Batteryspace (2015).

Table 9: Assumed content of critical metals in Ni-Cd batteries

\begin{tabular}{|c|c|c|c|}
\hline Critical Metal & Average content (weigh t\%) & Low range & High range \\
\hline Cobalt, Co & $0.6000 \%$ & & \\
\hline \multicolumn{4}{|l|}{ Indium, In } \\
\hline Lithium, Li & $19.23 \%$ & & \\
\hline \multicolumn{4}{|l|}{ Silver, Ag } \\
\hline \multicolumn{4}{|l|}{ Tantalum, Ta } \\
\hline \multicolumn{4}{|l|}{ Tungsten, W } \\
\hline \multicolumn{4}{|l|}{ Gold, $\mathrm{Au}$} \\
\hline \multicolumn{4}{|l|}{ Beryllium, Be } \\
\hline \multicolumn{4}{|l|}{ Gallium, Ga } \\
\hline \multicolumn{4}{|l|}{ Germanium, Ge } \\
\hline \multicolumn{4}{|l|}{ Palladium, Pd } \\
\hline Ruthenium, Ru & & & \\
\hline
\end{tabular}

\section{Nickel-metal-hydride batteries}

The average weight of a rechargeable Nickel-metal-hydride battery is assumed to $0.282 \mathrm{~kg}$ per unit based on Batteryspace (2015).

Table 10: Assumed content of critical metals in Ni-MH batteries

\begin{tabular}{|c|c|c|c|}
\hline Critical Metal & Average content (weight \%) & Low range & High range \\
\hline Cobalt, Co & $2.15 \%$ & $1.00 \%$ & $4.30 \%$ \\
\hline \multicolumn{4}{|l|}{ Indium, In } \\
\hline \multicolumn{4}{|l|}{ Lithium, Li } \\
\hline \multicolumn{4}{|l|}{ Silver, Ag } \\
\hline \multicolumn{4}{|l|}{ Tantalum, Ta } \\
\hline \multicolumn{4}{|l|}{ Tungsten, W } \\
\hline \multicolumn{4}{|l|}{ Gold, Au } \\
\hline \multicolumn{4}{|l|}{ Beryllium, Be } \\
\hline \multicolumn{4}{|l|}{ Gallium, Ga } \\
\hline \multicolumn{4}{|l|}{ Germanium, Ge } \\
\hline \multicolumn{4}{|l|}{ Palladium, Pd } \\
\hline Ruthenium, Ru & & & \\
\hline
\end{tabular}




\section{Lithium-Ion batteries}

\begin{tabular}{|c|c|c|c|}
\hline Critical Metal & Average content (weight \%) & Low range & High range \\
\hline Cobalt, Co & $12.23 \%$ & $3.15 \%$ & $20.00 \%$ \\
\hline \multicolumn{4}{|l|}{ Indium, In } \\
\hline Lithium, Li & $3.75 \%$ & $1.25 \%$ & $10.00 \%$ \\
\hline \multicolumn{4}{|l|}{ Silver, Ag } \\
\hline \multicolumn{4}{|l|}{ Tantalum, Ta } \\
\hline \multicolumn{4}{|l|}{ Tungsten, W } \\
\hline \multicolumn{4}{|l|}{ Gold, Au } \\
\hline \multicolumn{4}{|l|}{ Beryllium, Be } \\
\hline \multicolumn{4}{|l|}{ Gallium, Ga } \\
\hline \multicolumn{4}{|l|}{ Germanium, Ge } \\
\hline \multicolumn{4}{|l|}{ Palladium, Pd } \\
\hline Ruthenium, Ru & & & \\
\hline
\end{tabular}

The average weight of a lithium-ion battery is assumed to $0.8 \mathrm{~kg}$ per unit for laptops and tablets based on own estimates and the fact that lithiumion batteries are the main battery type used for laptops and cell phones.

\subsection{Data on environmental impacts}

\subsubsection{Introduction}

This section presents data for the environmental burdens associated with the recycling of the chosen critical metals, also data for the primary production of the same metals. The recycling data is based upon Life Cycle Assessment (LCA) calculations of the major Nordic e-scrap recycling facility (Boliden's Rönnskär smelter) and the primary production data from comprehensive assessments published in the literature. All of the major product groups assessed in this study apart from batteries (i.e. mobile phones, flat screens, laptops / notebooks, and PCs) form part of Rönnskär's high-grade electronic scrap feed. Batteries will require separate consideration that is not included here to date.

The burdens from the recycling and primary production data sets are used implicitly as a basis for comparison. The net environmental benefit of recycling a kilo of metal is the effective difference between the two burdens. This is the case when the recycled metal can be assumed to replace the primary-produced metal, hence avoiding the environmental cost of the latter. This comparison is presented in section 3.2. Below, we outline the supporting data and relevant LCA calculations. 


\subsubsection{Data for recycled critical metals}

Environmental impacts from recycling metal arise from two distinct sources: energy use within the recycling process and direct emissions from it. Each of these are calculated from public data on Boliden's operations (Boliden 2014a, 2014b, 2014c). The ultimate basis for the data is $1 \mathrm{~kg}$ of electronic scrap feed in the year 2014 .

The total energy use across the smelters in the Boliden group for 2014 was $20,109,000 \mathrm{GJ}\left(2,0109 * 10^{16} \mathrm{~J}\right)$. In the absence of more detailed information, this energy was allocated across the five different smelters in accordance with their total mass throughput. Rönnskär as a whole had a throughput of 845,000 tonnes, which was $32.5 \%$ of the total throughput of 2,598,000 tonnes. Thus, the total energy use at Rönnskär was taken to be about 6.5 million GJ which corresponds to about $7.74 \mathrm{GJ}$ or 2,150 kWh per tonne of throughput.

The majority of throughput at Rönnskär, as at the other smelters, is in the form of ore. Approximately $10 \%$ of the input $(82,000$ tonnes) was electronic scrap. However, it is known that recovering metals from scrap is much less energy-intensive than from ore; only around 15\% of the energy is required (Boliden 2011). Hence, the average energy use for a ton of electronic scrap is taken to be $15 \%$ of the average for the smelter as a whole (thus $323 \mathrm{kWh}$ ). For LCA purposes, this energy is assumed to take the form of high-voltage electricity. The energy balance shows that the majority of the energy used is indeed in the form of (purchased) electricity.

The main direct emissions from the smelters across the Boliden group are identified as $\mathrm{CO}_{2}, \mathrm{NOx}, \mathrm{SOx}$, particulates and metals (As, $\mathrm{Cd}, \mathrm{Cu}, \mathrm{Pb}, \mathrm{Zn}$ ) to air, and metals ( $\mathrm{Cu}$ and traces of others) to water (Boliden 2014a). Once more these emissions are allocated by mass, first to Rönnskär as a whole and thereafter to each tonne / kilo of electronic scrap feed. In summary, the environmental impacts per kilo of electronic scrap feed are calculated as follows:

Table 12: Environmental impacts from treating $1 \mathrm{~kg}$ of electronic scrap

\begin{tabular}{lr} 
Environmental impact category & Impacts/kg of e-scrap \\
High-voltage electricity & $0.323 \mathrm{kWh}$ \\
$\mathrm{CO}_{2}$ to air & $213,24 \mathrm{~g}$ \\
$\mathrm{NOx}$ to air & $0.24 \mathrm{~g}$ \\
SOx to air & $2.82 \mathrm{~g}$ \\
Particulates to air & $0.03 \mathrm{~g}$ \\
Metals to air & $0.01 \mathrm{~g}$ \\
Metals to water & $2.69 \mathrm{~g}$ \\
\hline
\end{tabular}


The main data are found to correspond closely with other studies of Boliden / Rönnskär operations published in the literature (Bigum et al., 2012). These data are then used for LCA calculations, with a range of environmental impact indicators and impact assessment methods as below. The calculations were performed using the SimaPro v8 LCA software. These indicators and methods were chosen to match those in the literature study of primary production (see 2.3 .3 below)

Table 13: Impact assessment methods used for the estimation of environmental impacts in each selected category

\begin{tabular}{lr} 
Indicator & $\begin{array}{r}\text { Impact Assessment Method } \\
\text { Global Warming Potential (GWP) }\end{array}$ \\
$\begin{array}{l}\text { Cumulative Energy Demand (CED) } \\
\text { Acidification Potential (AP) Eutrophication Potential (EP) } \\
\text { Human Toxicity Potential (HTP) }\end{array}$ & $\begin{array}{r}\text { CED v1.08 by ecoinvent } \\
\text { ReciPe midpoint (hierarchist perspective) v 1.12 } \\
\text { USEtox v 1.04 (recommended + interim factors) }\end{array}$ \\
\hline
\end{tabular}

The principal results per kilogram of e-scrap feed are as follows:

Table 14: Environmental impacts from treatment of electronic scrap expressed per selected impact category

\begin{tabular}{lrr} 
Global Warming Potential & $\mathbf{0 . 2 3 4}$ & $\mathbf{k g ~ C O}$ eqv. \\
Cumulative Energy Demand & 2.01 & $\mathrm{MJ}$ \\
Acidification Potential & 0.003 & $\mathrm{~kg} \mathrm{SO}$ eqv. \\
Eutrophication Potential & $5,899 * 10^{-6}$ & $\mathrm{~kg} \mathrm{P}$ eqv. \\
Human Toxicity Potential & $1,036 * 10^{-6}$ & CTUh \\
\hline
\end{tabular}

Based on an assumed composition of electronic scrap, these impacts are then allocated to recovery of specific critical metals. This is outlined in section 3.2.

\subsubsection{Data for primary production}

Nuss and Eckelman (2014) conducted an extremely comprehensive life cycle assessment study of the primary production of 63 metallic elements, including all 13 of the critical metals in our study. The broad aim was a better understanding of primary metals production with a view to better management of metals and sustainable resource use, Life cycle inventory data sets were combined with data from an extensive literature search, and LCA calculations performed - as in the present study - using the SimaPro software and a range of impact assessment methods.

In most cases the production routes are rather complex - often demanding the mining of an ore, followed by the purification of a 
concentrate, the refining of an intermediate and the separation of elemental material from mixes / alloys. There are numerous linked and joint production routes for different metals. Allocation of environmental burdens in these cases was usually pursued on an economic basis. Only the main results are shown here (Table 15), with further discussion in the sections below. All of the results are per kilogram of primary production of the given metal.

Table 15: Environmental impacts per kilo of critical metal extracted from the ground (primary production)

\begin{tabular}{|c|c|c|c|c|c|}
\hline & GWP $\left(\mathrm{CO}_{2}\right.$ eqv / kg) & CED (MJ / kg) & AP (kg SO2 / kg) & EP (kg P / kg) & HTP (CTU / kg) \\
\hline Co & 8.3 & 128 & $8.90 \mathrm{E}-02$ & 4.00E-03 & $3.80 \mathrm{E}-06$ \\
\hline $\ln$ & 102 & 1,720 & $1.20 \mathrm{E}+00$ & $1.50 \mathrm{E}-01$ & $1.70 \mathrm{E}-03$ \\
\hline $\mathrm{Li}$ & 7.1 & 125 & $3.80 \mathrm{E}-02$ & $6.10 \mathrm{E}-03$ & $3.70 \mathrm{E}-06$ \\
\hline $\mathrm{Ag}$ & 196 & 3,280 & $8.50 E+00$ & $3.60 \mathrm{E}+00$ & $6.90 \mathrm{E}-03$ \\
\hline $\mathrm{Ta}$ & 260 & 4,360 & $1.70 \mathrm{E}+00$ & $1.50 \mathrm{E}-01$ & $1.20 \mathrm{E}-04$ \\
\hline W & 12.6 & 133 & $2.90 \mathrm{E}-01$ & $9.30 \mathrm{E}-06$ & $3.40 \mathrm{E}-05$ \\
\hline $\mathrm{Au}$ & 12,500 & 208,000 & $1.20 \mathrm{E}+02$ & $2.30 \mathrm{E}+02$ & $3.90 \mathrm{E}-01$ \\
\hline $\mathrm{Be}$ & 122 & 1,720 & $5.20 \mathrm{E}-01$ & $3.10 \mathrm{E}-02$ & $2.10 E-05$ \\
\hline $\mathrm{Ga}$ & 205 & 3,030 & 4.50E-01 & $6.10 \mathrm{E}-02$ & $5.00 \mathrm{E}-05$ \\
\hline $\mathrm{Ge}$ & 170 & 2,890 & $1.90 \mathrm{E}+00$ & $2.60 \mathrm{E}-01$ & $2.90 \mathrm{E}-03$ \\
\hline $\mathrm{Pd}$ & 3,880 & 72,700 & $1.70 \mathrm{E}+03$ & $1.00 \mathrm{E}+01$ & $1.80 \mathrm{E}-02$ \\
\hline Ru & 2,110 & 41,100 & $3.00 E+02$ & $9.10 \mathrm{E}+00$ & $1.60 \mathrm{E}-02$ \\
\hline
\end{tabular}

It is immediately apparent that there are wide differences in the impact per kilo of production. Gold $\mathrm{(Au}$ ) and the platinum group elements (Pd and Ru here) are extremely burdensome to produce. Certain other critical metals (notably Co, Li and $\mathrm{W}$ ) are low-impact, comparable to bulk metals $(\mathrm{Pb}, \mathrm{Fe}, \mathrm{Cu}, \mathrm{Al})$ - at least in terms of global warming potential.

As discussed in numerous studies including that of Norgate and Haque (2012), the environmental impact of gold production is considerably higher than for most other metals - in some cases by orders of magnitude, as shown in the data here. The impact is largely attributable to the mining and mineral processing stage, and most of the impacts can be traced to the very low concentration of gold in the extracted ores compared to those for most other metals. This means a very high mass of ore per unit mass of metal must be processed, with huge energy and water requirements, and consequent solid waste burdens.

\subsubsection{Data uncertainty}

As outlined above, the data for metals recycling is subject to a host of assumptions in deriving the LCA model of the recycling process. Broad agreement - notably in the calculated energy load - between our 
calculations and previous studies (Bigum et al., 2012) provides some additional confidence in the results.

The uncertainty in the data is difficult to quantify. Some of the analysis is based on mass allocation of burdens across the Boliden group of smelters. Other than a much more detailed examination than was feasible for this study, sourcing difficult-to-obtain Rönnskär-specific data, it is difficult to envisage an approach in which one could have greater confidence. The energy load information seems reasonably safe, the mass allocation of direct emissions data perhaps a little less so. Economic rather than mass allocation (based on the value rather than mass of materials) would be possible in principle but necessarily based somewhat crudely on broad financial figures.

The only significant reported uncertainties in the primary production data concern only three of the critical metals in the present study (Ge, Ag and In) which are derived from a complex co-production chain ( $\mathrm{Pb}-\mathrm{Zn}$ system). The uncertainty (in global warming potential) is of the order of $20-50 \%$ in these cases.

\subsection{Data on economic value}

The value of any recycled material needs, as least partially, to cover the costs for collection, dismantling, sorting, and other activities necessary to make recycling possible. These costs are represented in the price of the recycled materials and is why recycling is driven by the material value. To simplify, metals are recycled if their value is high enough and if the necessary recycling technologies and infrastructure are in place (UNEP, 2013). But the reality is not as simple. Post-consumer recycling of critical metals are difficult mainly due to low metal concentrations in the waste flows and in single units of WEEE, and because critical metals are a minor constituent in a complex material matrix (UNEP, 2009). Plastics and steel tend to dominate WEEE in terms of weight, but looking at value, it is the precious metals that dominate. Precious metals are usually distinguished as gold, silver, and the platinum group metals (PGMs), including platinum, palladium and ruthenium, which all have a high economic value relative to other metals and also similar chemical and physical properties. Precious metals commonly make up more than $80 \%$ of the material value in PCs and mobile phones, and around 50\% of TV boards. A lower content of precious metals in WEEE consequently reduces the economic drivers for recycling (Hagelüken and Corti, 2010). The content of cobalt and 
nickel in rechargeable batteries drives the recycling of the batteries (UNEP, 2013).

Recycling rates tend to be higher when the metals are used in relatively large quantities in easily recoverable applications (e.g. lead in batteries) or, as mentioned, when the value of the recyclable metals is high. In this context it is possible to talk about economies of scale in recycling where the unit costs of recycling decrease when the supply of waste material increases (Van Beukering et al. 2014).

Despite the challenges facing recycling of critical metals, recycling of several of them is obviously viable. One explanation is that although the metal concentrations are low in the waste flows, they are nonetheless much higher than in natural ore. An example is an automotive catalyst where the content of platinum, palladium and rhodium is more than hundred times the concentration in natural ore (UNEP, 2009). UNEP estimates end-of-life recycling rates (EOL-RR), that is, the percentage of metals in discards that is actually recycled. Cobalt, gold, silver, and palladium are globally recycled to over $50 \%$. Tungsten and ruthenium are recycled to around $10-25 \%$, and lithium, beryllium, germanium, gallium, indium and tantalum to below one percent. UNEP has also estimated the global average recycled content, expressed as the fraction of secondary metal in the total metal input to metal production ranges from below one percent for lithium to over $50 \%$ for ruthenium. The end-of-life recycling rate and the average recycled content are presented in Table 13. The average recycled content is for both new and old scrap.

Table 16: End-of-life recycling rates and global average recycled content for the selected critical metals (UNEP, 2011)

\begin{tabular}{|c|c|c|}
\hline Critical Metal & $\begin{array}{r}\text { End-of-life recycling rates (EOL-RR, } \\
\text { the percentage of metals in discards } \\
\text { that is recycled) }\end{array}$ & $\begin{array}{r}\text { Global average recycled content (RC, } \\
\text { the fraction of secondary metal in the } \\
\text { total metal input to metal } \\
\text { production) }\end{array}$ \\
\hline Cobalt, Co & $>50 \%$ & $25-50 \%$ \\
\hline Indium, In & $<1 \%$ & $25-50 \%$ \\
\hline Lithium, Li & $<1 \%$ & $<1 \%$ \\
\hline Silver, Ag & $>50 \%$ & $25-50 \%$ \\
\hline Tantalum, Ta & $<1 \%$ & $10-25 \%$ \\
\hline Tungsten, W & $10-25 \%$ & $25-50 \%$ \\
\hline Gold, Au & $>50 \%$ & $25-50 \%$ \\
\hline Beryllium, Be & $<1 \%$ & $10-25 \%$ \\
\hline Gallium, Ga & $<1 \%$ & $10-25 \%$ \\
\hline Germanium, Ge & $<1 \%$ & $25-50 \%$ \\
\hline Palladium, Pd & $>50 \%$ & $25-50 \%$ \\
\hline Ruthenium, Ru & $10-25 \%$ & $>50 \%$ \\
\hline
\end{tabular}




\section{Trading of metals}

The history of the metal market dates back to the $17^{\text {th }}$ century when a need to standardize commodities emerged (Råvaruhandeln, 2012).

A commodity is a standardized product sold with little or no differentiation by the producers or suppliers, as long as it meets certain minimum criteria or specifications. There are various official commodities exchanges where metals or related derivatives are traded, such as the London Metal Exchange (LME), the New York Mercantile Exchange (NYMEX), the Tokyo Commodity Exchange (TOCOM), Dubai Gold \& Commodities Exchange (DGCX). Each market focus on particular metals; for example, steel, aluminum, copper, lead, nickel, tin, zinc, molybdenum and cobalt are traded on the LME. The same metal can of course be traded on different markets; for example, gold is traded in London under the auspices of ICE (International Commodity Exchange), but also in the USA under the Chicago Mercantile Exchange (CME) or in Tokyo under TOCOM etc.

Metals traded on the global metal markets are metals available in a relatively high quantity, with a high number of players and high transaction frequency, the latter often referred to as "liquidity". Metals of less global importance are not traded on the official exchanges, but can of course be traded at the one-to-one transaction level, between two contracting parties. This is the case for indium, lithium, tantalum, tungsten, beryllium, gallium and germanium, amongst others. Though not traded on commodity exchanges, prices for those metals (often called "minor metals") can nevertheless be found in specialized publications such as Metal Bulletin, Metals Week, Asian Metal etc. These process are based on an analysis of inputs from buyers, sellers, mining companies, industrial consumers etc. Prices tend to be published on bi-weekly, weekly or monthly basis. Those prices are only indications, but they can be used through pricing formulas in long term sales and purchase contracts if they are considered a correct reflection of the market (Van Maele, 2016).

Metals can be traded in physical quantities and in futures market, where future contracts are purchased and sold for delivery on a specific date in the future. The supply of metals in the short-run is determined by how fast ore deposits can be mined and the release of reserves. The supply conditions can quickly change: discoveries of new depositories and thereby new mining opportunities, export control policies, and governmental protectionist measures all influence supply. The demand is derived from manufacturing and construction sectors. Demand booms often occur when countries, often emerging economies, increase imports of metals for construction or infrastructure purposes (Espinoza, 2012). 
The average prices of metals in 2015 went down 21\% compared to 2014. In December, the World Bank Metals and Minerals Price Index was 55\% below the high reached in February 2011. Metals prices are projected to decline, by $10 \%$ in 2016 due to low demand in emerging market economies (especially China), and increases in new production capacity. The prices of precious metals are also expected to decline. The price of silver is expected to drop by $11 \%$, and gold prices by $7 \%$ (World Bank, 2016).

The prices of the selected metals are presented in Table 17. The metals are traded in different units, but the prices are recalculated to EUR per kg.

When it comes to metals traded on commodity exchanges, both primary and secondary metals are traded on the same premises and priced the same as long as they meet the requirements set by the exchange. It is generally the quality as opposed to the origin that sets the price. This however does not automatically mean that the origin has no role to play; as an example, we can mention here that in order to be classified as a "London Good Delivery" producer of gold by the London Bullion Market Association and be traded in London under the auspices of ICE, the producer needs to pass certification according to the LBMA Responsible Gold Guidance, itself based on the OECD Due Diligence Guidance as well as Swiss and US KYC, Anti-Money Laundering and Combating Terrorist Financing regulations. (Van Maele, 2016).

This, however, should not be confused with value of unrefined WEEE scrap. The prices listed in Table 17 are taken from the U.S. Geological Survey, and represents average prices for 2015.

Table 17: Average prices of metals for 2015 (U.S. Geological Survey, 2016)

\begin{tabular}{lr} 
Critical Metal & EUR per kg \\
Cobalt, Co & 20.7 \\
Indium, In & 0.49 \\
Lithium, Li & 5.8 \\
Silver, Ag & 465 \\
Tantalum, Ta & 47 (tantalite, dollars per kg of TaO content) \\
Tungsten, W & 29 (concentrate, dollars per kg WO ${ }_{3}$ ) \\
Gold, Au & 34,013 \\
Beryllium, Be & 268 \\
Gallium, Ga & 1602 \\
Germanium, Ge & 20,059 \\
Palladium, Pd & 1,395 \\
Ruthenium, Ru & 463 (beryllium-copper master alloy, dollars per kg contained beryllium) \\
\hline
\end{tabular}




\subsection{Issues around data credibility}

The data collection around the presence, fate, environmental and economic implications of critical metals in WEEE is not without challenges. Data gaps on one hand and data uncertainty on the other, reduce the confidence on the data collected. The results of this study are only as credible as the data used.

Specific issues have been identified in the data acquisition process related to waste data, content of critical metals in the selected product groups, and environmental and economic data.

Data on annual quantity of critical metals in waste in the Nordic region are compiled through the estimation of discarded selected products and their content in critical metals. Discarded products are estimated through sales data and average life spans. One underlying assumption that could be considered as a source of uncertainty is that the calculations assume that all purchased products will be discarded at the end of their life spans, thus excluding stockpiling.

Issues arise also when investigating the critical metals content in the selected product groups. Although the literature used is very robust, the existing data gaps might reflect the absence of a certain metal from a product or, alternatively, the lack of documentation for its presence. Therefore, the quantities of some critical metals arising in the waste might be underestimated.

Uncertainty around the environmental data can be found not so much in the datasets themselves but rather on some methodological assumptions included in the LCA calculations. Allocation of environmental impacts to different co-processed materials by mass or by economic value is a methodological choice that adds uncertainty on the results.

Regarding economic data, information on the virgin materials is used, due to lack of economic data on secondary materials. This is considered as a good proxy, as the quality of the reclaimed critical metals is comparable to metals from virgin ores.

Despite using the best available databases and most recent and credible literature, assumptions and data shortcomings add uncertainty to the calculations presented in this study. However, the level of uncertainty still permits the analysis on the critical metals waste flows and drawing conclusions on their treatment status quo. The final results, however, should not be considered definitive, but rather as a best estimate. 



\section{Critical metals in the Nordic WEEE}

\subsection{Critical metals quantities in Nordic WEEE}

Assessing the potential for recovery of the selected critical metals, the related environmental consequences and economic impacts, necessitates an estimate of the total arisings of these metals in the Nordic region, from the five product groups. This estimate is explored over the years 2015-2020 in order to show a forward-looking perspective and allow for policy planning.

The estimated quantities of critical metals have, as a starting point, the annual quantities of discarded products (mobile phones, PCs, flat screen TVs, notebooks/laptops and rechargeable batteries) and their content in critical metals. This content is considered stable throughout the projection period, as no information exists to the authors' knowledge on current and future changes in constructing the products in question. It should be noted that this is a further source of uncertainty. The annual discarded quantities of the selected products have already been presented in chapter 2.1.

By multiplying the content of critical metals in each product group with the annual discarded quantities of the product in each Nordic country, annual discarded quantities can be calculated for each metal and each product in each Nordic country.

Several issues arose during this process:

- Data on Germanium in the selected product groups is not available.

Therefore, due to lack of data, Germanium is excluded from further analysis.

- The Lithium content in mobile phones is ignored, as this content refers to the phone battery, which is examined separately in this study. So, in order to avoid double-counting, mobile phones are assumed to have no lithium content.

Below, the sum of all discarded quantities of each critical metal from all product groups is presented per country for 2015-2020. For these estimations, the average metal content is used (see chapter 2.2). By using 
the minimum or maximum metal content ranges, ranges for the estimates per critical metal can be calculated. This has not been done in this report.

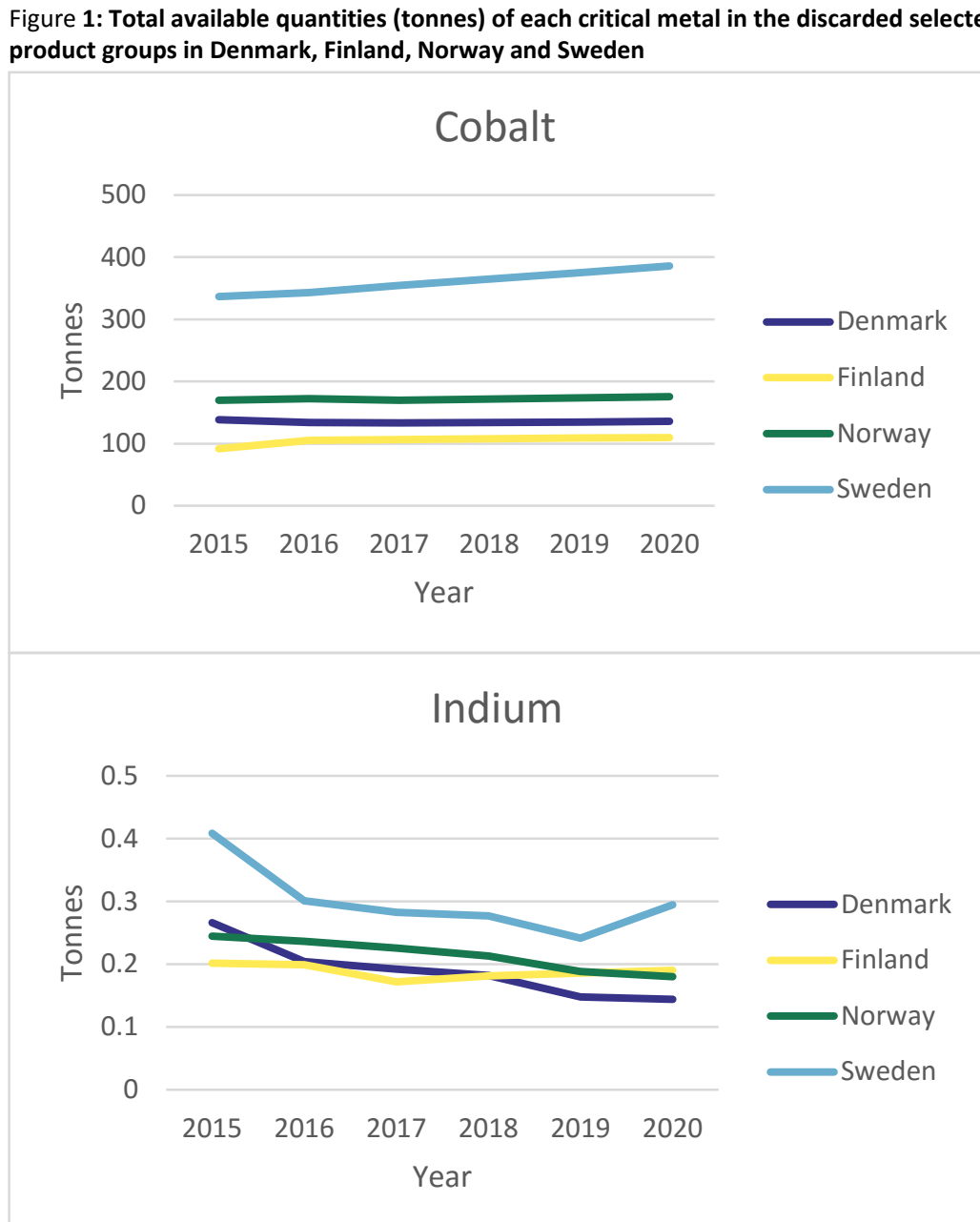




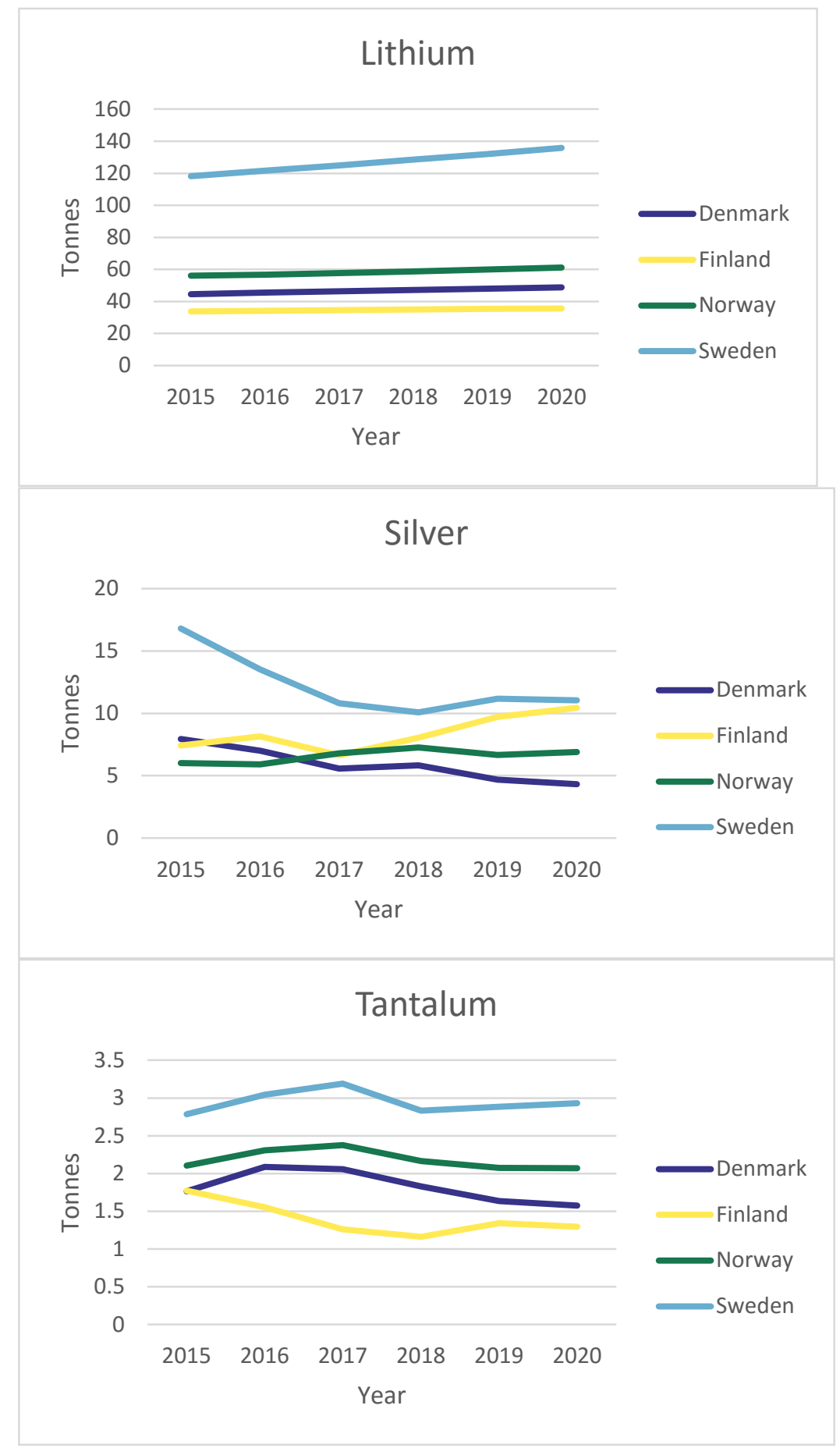




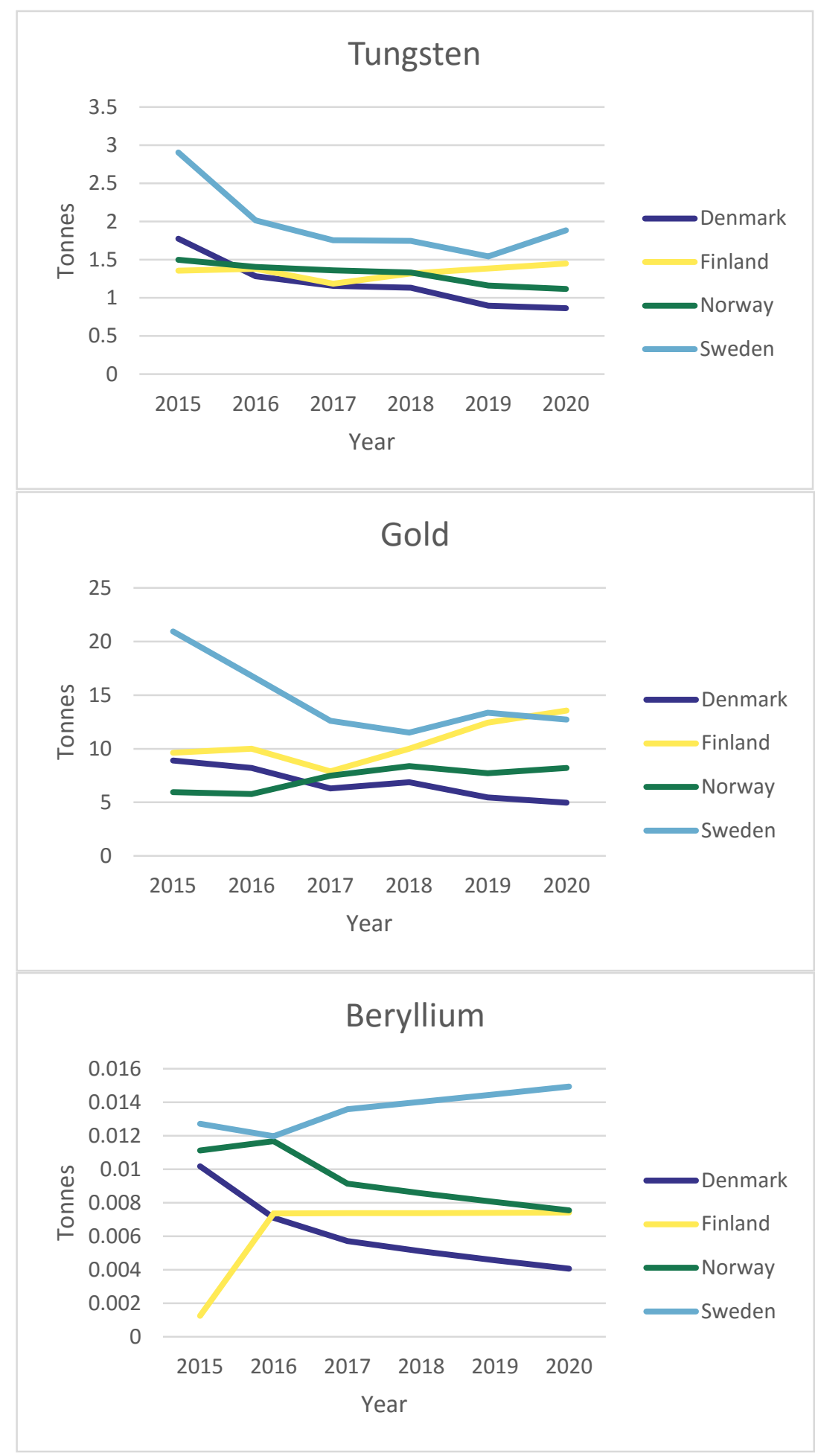




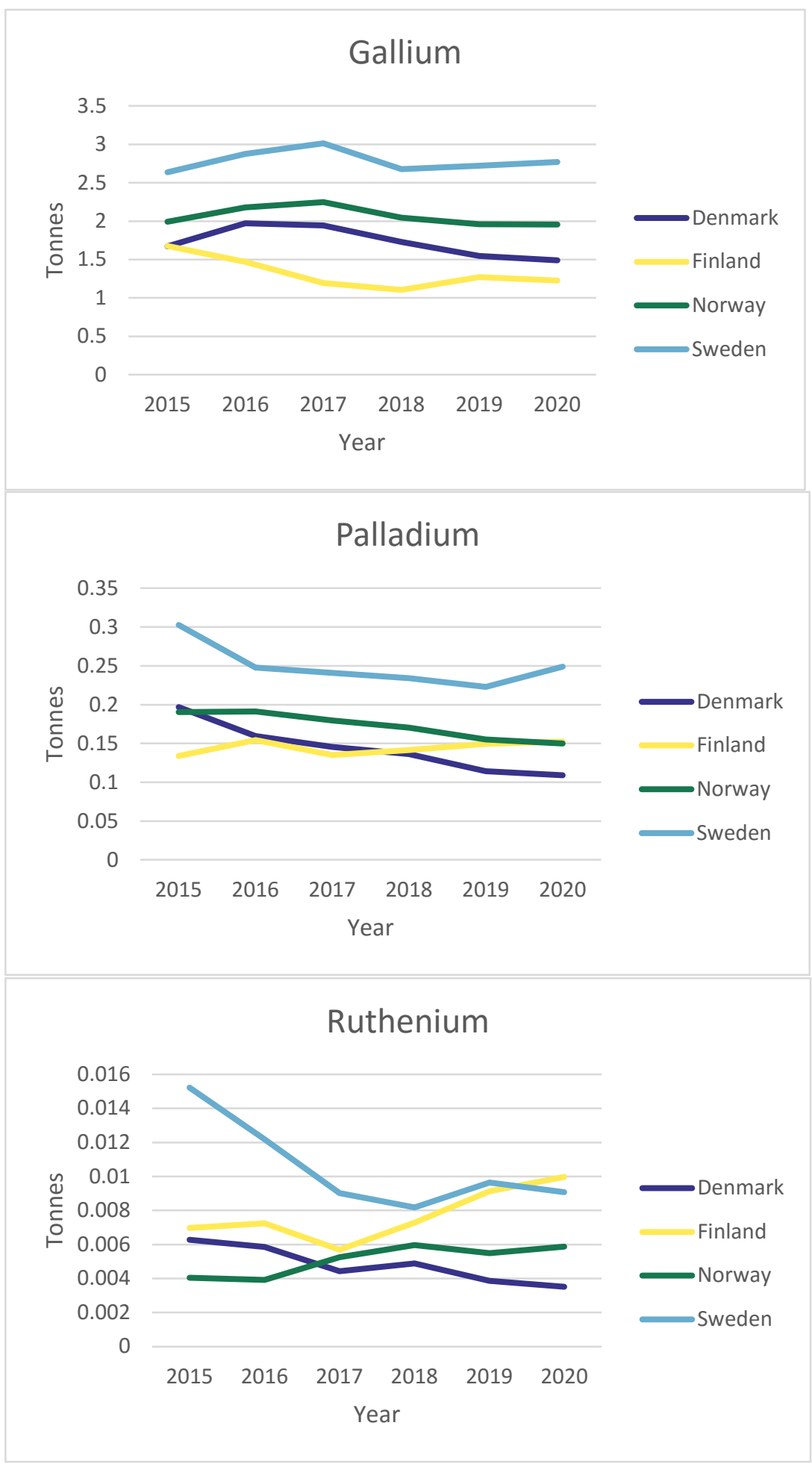


Table 18: Total available metal quantities (tonnes) in all product groups' wastes and in all Nordic countries examined

\begin{tabular}{lrrrrrr} 
Critical Metal & $\mathbf{2 0 1 5}$ & $\mathbf{2 0 1 6}$ & $\mathbf{2 0 1 7}$ & $\mathbf{2 0 1 8}$ & $\mathbf{2 0 1 9}$ & $\mathbf{2 0 2 0}$ \\
Cobalt & & & & & \\
Indium & 736 & 755 & 764 & 778 & 792 & 807 \\
Lithium & 1 & 0.94 & 0.87 & 0.85 & 0.76 & 0.81 \\
Silver & 253 & 258 & 263 & 269 & 275 & 281 \\
Tantalum & 38 & 35 & 30 & 31 & 32 & 33 \\
Tungsten & 8 & 9 & 9 & 8 & 8 & 8 \\
Gold & 8 & 6 & 5 & 6 & 5 & 5 \\
Beryllium & 45 & 41 & 34 & 37 & 40 & 39 \\
Gallium & 0.04 & 0.04 & 0.04 & 0.04 & 0.03 & 0.03 \\
Palladium & 8 & 9 & 8 & 8 & 8 & 7 \\
Ruthenium & 0.82 & 0.75 & 0.70 & 0.68 & 0.64 & 0.66 \\
& 0.032515 & 0.02921 & 0.024385 & 0.026308 & 0.028109 & 0.028429 \\
\hline
\end{tabular}

The presented estimations indicate that no major developments are expected in the waste arisings of the critical metals in the future. However, it should be underlined that new designs of electronics have not been taken account (i.e. metal content, as a percentage of product weight, is assumed stable).

The largest arisings are identified for Cobalt and Lithium due to the rechargeable batteries high content of these two metals. Silver and gold follow in terms of available quantities and then Tantalum and Gallium.

As already suggested, the recovery of most of these metals is either trivial or non-existent. However, our estimates show that if the technological or other barriers are removed the potentially available quantities of these metals in the selected product groups is significant, with for instance around 45 tonnes of gold available in 2015. The results presented here correspond to the selected product groups only. Although other product groups are expected to have relatively lower content of critical metals, the potentially available quantities from the entire WEEE stream should be a lot higher than those presented here.

In the following chapters, the potentially available metal quantities are examined with respect to their environmental and economic significance. 


\subsection{Discussion on environmental impacts}

\subsubsection{Introduction}

In this section we take the LCA calculations for recycling and primary production outlined in section 2.3 above, and compute the total burdens and benefits that would arise, were all the critical metals recovered from the electronic scrap feed to Boliden's Rönnskär smelter.

\subsubsection{Process description}

Following the analysis of Bigum et al. (2012), we take the electronic scrap feed to be high-grade WEEE which is subject to a host of pre-treatment steps including manual sorting, shredding, air sorting, magnetic sorting, eddy current sorting and optical sorting. This results in the separation of many fractions - principally glass, plastics, ferrous metals and aluminium. Thereafter, several steps of metallurgical treatment (Kaldo plant, converter aisle, anode refining) serve to remove lead, copper and nickel. The remaining metallic mix is then fed to the "precious metals refinery" which is the specific basis for analysis here.

We assume that all the critical metals of interest in this study survive the various pre-processing steps and are dealt-with in the precious metals refinery. In principle it seems likely that at least some of the critical metals will be trapped by the previous steps. However, from the overall environmental point of view it looks fairly safe that most of the relevant impacts will be "captured" correctly. We can be fairly certain that the precious high-value metals $(\mathrm{Au}, \mathrm{Ag}, \mathrm{Pd}$ in particular) which carry most of the impacts are in the feed as far as possible - although as shown below, losses of metals along the whole processing chain are likely to be quite substantial.

\subsubsection{Metals recovery and environmental impacts}

In this section we derive an estimate for the total recovery of critical metals from the WEEE recycling process and the associated environmental impacts and savings (of avoided production), per unit mass of scrap feed.

To do this we take the LCA calculations for recycling and primary production outlined in section 2.3 above, and compute the total burdens and benefits that would arise, were all the critical metals recovered from the electronic scrap feed to Boliden's Rönnskär smelter. Batteries are 
subjected to an entirely separate treatment path, for which a reliable LCA model is not available at present. Hence, batteries are completely excluded from all the environmental impact analyses.

We first require an estimate of the composition of the e-scrap feed entering the Boliden treatment chain. We effectively assume that the four product groups (mobile phones, flat screens, laptops / notebooks and PCs) provide a fully representative sample of all the e-scrap entering the facility. According to Bigum et al. (2012), the "high-grade WEEE" feed contains products from categories \#3 and \#4 in the WEEE Directive (namely IT and telecommunications equipment, and consumer equipment). It therefore seems reasonable that our four product groups represent a reasonable sample of the full spectrum of products in the actual feed to the facility.

The relative amounts of each product in the feed are assumed from data on waste generation as described in section 2.1 above, which in turn are based on sales data combined with expected lifetimes of equipment. Taking that data for 2014 and rounding to the nearest $5 \%$ in each case gives the assumed composition of the feed by mass to be: $5 \%$ mobile phones; $55 \%$ flat screens; $10 \%$ Laptops and notebooks; $30 \%$ PCs.

We then combine these fractions with the data on average content of critical metals per product group as described in section 2.2 above. This gives an average content of critical metals per kilogram of scrap feed, as in Table 19.

Table 19: Average content of critical metals per kilogram of scrap feed

$\begin{array}{lr}\text { Critical Metal } & \text { Average content } \mathbf{( k g}) \text { per } \mathbf{k g} \text { of scrap feed } \\ \text { Cobalt, Co } & \\ \text { Indium, In } & 1.12 \mathrm{E}-03 \\ \text { Lithium, Li } & 1.21 \mathrm{E}-05 \\ \text { Silver, Ag } & 0.00 \mathrm{E}+00 \\ \text { Tantalum, Ta } & 3.32 \mathrm{E}-04 \\ \text { Tungsten, W } & 9.51 \mathrm{E}-05 \\ \text { Gold, Au } & 7.70 \mathrm{E}-05 \\ \text { Beryllium, Be } & 3.52 \mathrm{E}-04 \\ \text { Gallium, Ga } & 5.17 \mathrm{E}-07 \\ \text { Germanium, Ge } & 9.00 \mathrm{E}-05 \\ \text { Palladium, Pd } & 0.00 \mathrm{E}+00 \\ \text { Ruthenium, Ru } & 9.27 \mathrm{E}-06 \\ & 2.45 \mathrm{E}-07\end{array}$

Table 19 gives the amounts of critical metals that would be recovered from 1 kilogram of e-scrap feed, were the materials recovered with $100 \%$ efficiency. In Table 21, this data is combined with that for primary production of metals (Table 15 in section 2.3.3) which gives the total 
environmental saving from $1 \mathrm{~kg}$ of scrap feed, subject to the same assumption of $100 \%$ recovery.

Table 20: Total environmental impact saving from avoided production, per kilogram of electronic scrap feed

\begin{tabular}{lrrrr} 
& GWP $\left(\mathrm{CO}_{2}\right.$ eqv $\left./ \mathbf{~ k g}\right)$ & AP $(\mathbf{k g ~ S O 2} / \mathbf{~ k g})$ & EP $(\mathbf{k g ~ P ~ / ~ k g ) ~}$ & HTP (CTU / kg) \\
\hline Cobalt, Co & & & & \\
Indium, In & $9.37 \mathrm{E}-03$ & $1.00 \mathrm{E}-04$ & $4.52 \mathrm{E}-06$ & $4.29 \mathrm{E}-09$ \\
Lithium, Li & $1.24 \mathrm{E}-03$ & $1.45 \mathrm{E}-05$ & $1.82 \mathrm{E}-06$ & $2.06 \mathrm{E}-08$ \\
Silver, Ag & $0.00 \mathrm{E}+00$ & $0.00 \mathrm{E}+00$ & $0.00 \mathrm{E}+00$ & $0.00 \mathrm{E}+00$ \\
Tantalum, Ta & $6.52 \mathrm{E}-02$ & $2.83 \mathrm{E}-03$ & $1.20 \mathrm{E}-03$ & $2.30 \mathrm{E}-06$ \\
Tungsten, W & $2.47 \mathrm{E}-02$ & $1.62 \mathrm{E}-04$ & $1.43 \mathrm{E}-05$ & $1.14 \mathrm{E}-08$ \\
Gold, Au & $9.71 \mathrm{E}-04$ & $2.24 \mathrm{E}-05$ & $7.17 \mathrm{E}-10$ & $2.62 \mathrm{E}-09$ \\
Beryllium, Be & $4.41 \mathrm{E}+00$ & $4.23 \mathrm{E}-02$ & $8.11 \mathrm{E}-02$ & $1.37 \mathrm{E}-04$ \\
Gallium, Ga & $6.31 \mathrm{E}-05$ & $2.69 \mathrm{E}-07$ & $1.60 \mathrm{E}-08$ & $1.09 \mathrm{E}-11$ \\
Germanium, Ge & $1.85 \mathrm{E}-02$ & $4.05 \mathrm{E}-05$ & $5.49 \mathrm{E}-06$ & $4.50 \mathrm{E}-09$ \\
Palladium, Pd & $0.00 \mathrm{E}+00$ & $0.00 \mathrm{E}+00$ & $0.00 \mathrm{E}+00$ & $0.00 \mathrm{E}+00$ \\
Ruthenium, Ru & $3.60 \mathrm{E}-02$ & $1.58 \mathrm{E}-02$ & $9.27 \mathrm{E}-05$ & $1.67 \mathrm{E}-07$ \\
Total for all metals & $5.18 \mathrm{E}-04$ & $7.36 \mathrm{E}-05$ & $2.23 \mathrm{E}-06$ & $3.93 \mathrm{E}-09$ \\
& 4.5629 & 0.0612 & 0.0824 & 0.00014 \\
\hline
\end{tabular}

Considering the precious metals refinery step alone, the assumption of $100 \%$ recovery would not be too inaccurate - according to Bigum et al. (2012) and sources therein, the actual recovery rates for precious metals are $98 \%$ or higher. However, there are substantial losses along the pretreatment chain and these cannot be ignored. In line with information in the key literature we take the pre-treatment recovery fraction for each of the critical metals to be $25 \%$. This assumption would merit more detailed attention, but field data would be hard to derive since most of the above metals are not actually recovered at present.

Based on this assumption, the total environmental benefit from metals recovery is only $25 \%$ of that given above. These benefits are then compared with the total environmental cost of recycling $1 \mathrm{~kg}$ of electronic scrap (in section 2.3.2) to give the comparison of net environmental costs and benefits.

Table 21: Net environmental benefits and costs from electronic scrap recycling, per kilogram scrap

\begin{tabular}{lrrrr} 
& GWP (CO $\mathbf{2}$ eqv / kg) & AP (kg SO2 / kg) & EP (kg P / kg) & HTP (CTU / kg) \\
Total benefit & 1,1407 & 0.0153 & 0.0206 & $3,498 \mathrm{E}-5$ \\
Total cost & 0.2340 & 0.0030 & $5,899 \mathrm{E}-6$ & $1.036 \mathrm{E}-6$ \\
Net benefit & 0.9067 & 0.0123 & 0.0206 & $3,396 E-5$ \\
Benefit / cost & 4.87 & 5.06 & 3491,9 & 33.78 \\
\hline
\end{tabular}

The results show that there is a clear overall environmental advantage, across all impact categories, from recycling critical metals. For example, recovering critical metals is almost five times as efficient from the GWP 
perspective as the production of virgin material. This of course assumes that the recycled material can, and is, integrated into existing markets as a one-to-one replacement for virgin material. Whilst such an assumption is problematic for many types of recycled materials owing to many and varied concerns on quality and utility, for recycled (precious) metals it is probably reasonably safe.

The effects and impacts of gold overwhelms those of all other metals in the analysis. Recovery of gold provides over $97 \%$ of the benefit of avoided production for the whole spectrum of critical metals with respect to GWP, EP and HTP, and nearly $75 \%$ of the total benefit for AP. The broad conclusions of the study are quite robust to changes in the underlying data regarding gold. It would require the proportion of gold in the feed to be overstated by a full order of magnitude, or for the overall recovery rate to fall below $4 \%$ (from $25 \%$ ), for the basic conclusion regarding recycling being advantageous over primary production, to become questionable. Even if the proportion of gold was only $10 \%$ of what it is assumed to be now, gold recovery would still dominate the overall picture for GWP, EP and HTP.

\subsubsection{Potential for environmental benefits from critical metals recovery}

There is considerable potential environmental benefit from critical metals recovery, both for existing e-scrap operations and for Nordic electronic waste more generally. The above calculations show that, if existing operations at Boliden were focused on critical metals, a potential GWP benefit of nearly $1 \mathrm{~kg} \mathrm{CO}_{2}$ equivalent per kilo of e-scrap feed could be achieved. The 82,000 tonnes of feed per annum would give rise to a net benefit of around 75,000 tonnes $\mathrm{CO}_{2}$ equivalent. To place that figure in context, the total annual emissions for all activities in Sweden are of the order of 50 million tonnes $\mathrm{CO}_{2}$ equivalent. This means that critical metals recovery offers an opportunity for nationallysignificant emissions reduction (corresponding to about $0.15 \%$ of the total emissions output of the entire country). The potential benefits are even larger if the recovery rates of critical metals could be increased.

The figure of 75,000 tonnes $\mathrm{CO}_{2}$ equivalent savings of course refers only to the known, existing electronic scrap feeds to Boliden. In principle the data can be scaled to cover all critical metals in Nordic electronic waste. We do this by taking the data in section 2.1 (Table 3) for total annual waste generation from 2015-2020 and recalculating data shown 
in section 3.2.3, specifically analogues of Tables 19 and 20, across all Nordic e-waste (in the given product groups).

This gives estimates for the total environmental burdens of recycling and benefits of avoided production, if all Nordic e-waste (in the relevant product groups) were subjected to a well-managed recycling process that focused on critical metals recovery. It assumes that recovery of other critical metals would not present substantial environmental burdens above and beyond that seen in existing practice. Burdens of recovery are small compared to the related benefits in any case, so considerable uncertainty in the data on burdens would not greatly affect the overall result, which is shown in Table 22 .

Table 22: Projected net environmental benefits from critical metals, if all Nordic electronic waste is subject to well-managed recycling, 2015-2020

\begin{tabular}{|c|c|c|c|c|}
\hline & $\begin{array}{r}\text { GWP } \\
\text { (ton } \mathrm{CO}_{2} \text { eqv) }\end{array}$ & $\begin{array}{r}\text { AP } \\
\text { (ton SO2 eqv) }\end{array}$ & $\begin{array}{r}E P \\
\text { (ton } P \text { eqv) }\end{array}$ & $\begin{array}{r}\text { HTP } \\
\text { (CTU) }\end{array}$ \\
\hline 2015 & 559,668 & 6,911 & 10,592 & 17,889 \\
\hline 2016 & 504,944 & 6,253 & 9,521 & 16,085 \\
\hline 2017 & 424,418 & 5,367 & 8,013 & 13,532 \\
\hline 2018 & 454,790 & 5,639 & 8,578 & 14,491 \\
\hline 2019 & 483,657 & 5,861 & 9,086 & 15,360 \\
\hline 2020 & 489,125 & 5,945 & 9,201 & 15,552 \\
\hline
\end{tabular}

The decline in the overall figures is owing to a projected decline in the amount of electronic waste from most product groups, but particularly flat-screen devices, over the period. It appears from the figures that the majority of electronic waste containing critical metals already passes through Boliden, since the estimated figures for all Nordic e-waste only exceed those for all waste through Boliden by perhaps $25-30 \%$.

\subsubsection{Discussion and conclusions}

Recycling of critical metals is unquestionably beneficial in environmental terms over virgin production. Despite the many and varied assumptions that were necessary to complete this analysis, it seems clear that recycling will always be favourable under any reasonable set of assumptions. The overall potential benefit of critical metals recycling is considerable, at around $0.2 \%$ of total national emissions for Sweden, or around 20,000 person-equivalents.

Unless and until the composition of electronic equipment changes substantially from its current state, the absolute primacy of gold in these calculations seems certain. In a broader perspective there are one or two other metallic elements that are not in the list of critical metals here but 
have enormous environmental impacts per kilo. Rhenium is not present in consumer electronic equipment, but platinum may be (although not at the level of gold). Rare earth elements are often quoted as both environmentally and economically important, yet the literature analysis suggests that from the pure environmental perspective, only scandium production presents any serious impacts compared to the platinum group metals with respect to the relevant indicators. It nonetheless seems likely that inclusion of certain indicators (especially relating to resource use) and more detailed consideration of others (relating to toxicity and occupational health effects; see Pagano et al, 2015) could raise the importance of rare earths in the overall analysis quite significantly.

As things stand in the present study, gold represents over $97 \%$ of the potential environmental savings from e-scrap recycling - and gold, silver and palladium combined constitute over $99 \%$ of the potential savings. It does not seem likely that missing or uncertain data regarding any of the other critical metals is likely to change the picture substantially. Given that, for the most part, the environmentally most "expensive" metals are also those with the highest economic value, it seems rather unlikely that the conclusions will change in the economic perspective.

The inevitable conclusion is that ongoing efforts to improve critical metals recycling from electronic waste should, in the first instance, focus primarily on gold for maximum effect in the environmental impact perspective.

\subsection{Discussion on economic consequences}

The drivers for recycling of WEEE could be direct economic motives, but also to avoid or decrease waste disposal costs, due to legislative requirements and policy, due to increased public concern about health and environmental impacts of waste disposal, and concerns of scarcity of natural resources (Van Beukering et al. 2014).

The economic consequences of recycling critical metals present in the selected product groups in the Nordic countries are challenging to estimate. The costs for primary production of the critical metals should ideally be compared to costs of recycling the critical metals present in the product groups. Such a comparison would reflect the economic consequences of increased recycling of critical metals in WEEE. However, such comparisons are complicated by the fact that available information is scarce, and information suitable for comparisons has not been found in 
this project. Another complicating factor is the production chains surrounding extraction of critical metals where the metals in focus could, for example, be by-products of bulk metal extraction, which makes allocation of costs to a single metal problematic. For example; platinum, palladium and rhodium tend to occur in the same primary deposit in association with iron sulphides and sulphides of nickel, cobalt and copper (Ayres et al., 2014). The same problem applies for the recycling costs as several metals are recycled in the same processes. State-of-the art recovery technologies for the selected critical metals is to use a large scale integrated smelter-refinery, such as the Umicore plant, where various kinds of WEEE fractions such as circuit boards and mobile phones are treated through a complex metallurgical flow sheet (Hagelüken and Corti, 2014). The Umicore plant in the Netherlands recovers and sells silver, gold, platinum, palladium, rhodium, iridium, ruthenium, indium, selenium, tellurium, antimony, tin, bismuth, as well as base metals (Umicore, 2015).

Despite the above mentioned obstacles to compare primary production costs to recycling costs, the market value of the critical metals in the Nordic WEEE can roughly be estimated based on the estimated quantities of critical metals in WEEE from Chapter 3.1 and the market prices for the critical metals listed in Chapter 2.4. The estimations should be seen as theoretical in the sense that they are calculated based on a number of assumptions that might not be valid in reality. They are valid if the total quantity of critical metals in WEEE was possible to recycle into secondary metals with the same quality as primary metals. We know this is not true as all of the generated WEEE is not collected, and that the total quantity of critical metals is not recyclable. Although, the figures should be seen as a theoretical example it gives us a hint of the potential economic value of the critical metals present in the generated Nordic WEEE for 2015 is around 1,600 million euros. The highest economic value is by far represented by gold. The estimations are presented in Table 24 . 
Table 23: Value of critical metals in Nordic WEEE (figures for 2015)

\begin{tabular}{lrrr} 
Critical Metal & $\begin{array}{r}\text { Value } \\
\text { (EUR per kilo) }\end{array}$ & $\begin{array}{r}\text { Quantity of critical metals in } \\
\text { Nordic WEEE, 2015 (tonnes) }\end{array}$ & $\begin{array}{r}\text { Value of critical metals in } \\
\text { Nordic WEEE (EUR) }\end{array}$ \\
\hline Cobalt, Co & 20.6 & 736 & 15.2 million EUR \\
Indium, In & 491 & 1.12 & 0.55 million EUR \\
Lithium, Li & 5.8 & 253 & 1.47 million EUR \\
Silver, Ag & 465 & 38.2 & 17.8 million EUR \\
Tantalum, Ta & 177 & 8.42 & 1.49 million EUR \\
Tungsten, W & 29.1 & 7.54 & 0.22 million EUR \\
Gold, Au & 34,013 & 45.4 & 1,544 million EUR \\
Beryllium, Be & 463 & 0.0353 & 16,400 EUR \\
Gallium, Ga & 268 & 7.98 & 2.14 million EUR \\
Palladium, Pd & 20,059 & 0.82 & 16.5 million EUR \\
Ruthenium, Ru & 1,395 & 0.0325 & 45,300 EUR \\
TOTAL & & & 1,599 million EUR \\
\hline
\end{tabular}




\section{Proposals for a Nordic region strategy}

\subsection{Proposals for improved waste management}

As our analysis shows, there are significant environmental and economic benefits associated with the recovery of critical metals from WEEE. Note that the focus is only on a handful of selected product groups, hinting that the potential for benefits could be much higher when the entire WEEE stream is taken into account. However, recovery of critical metals is relatively low in general, while focus is given only on a few selected metals of very high economic value, such as gold.

Further exploitation of waste resources for extracting critical metals would lead to the full exploration of the benefits potential both in environmental and economic terms. However, there are a number of barriers that hinder the further development of the recycling processes.

First of all, existing recycling technologies cannot guarantee the comprehensive targeting of a wide range of critical metals. The isolation of each metals from the WEEE scrap is complicated and only a few high tech plants exist in Europe, that are able to extract the critical metals in question. Research in technological innovation might offer new, better solutions for extracting simultaneously various metals from the scrap.

The fact that only a few installations exist is also based on the economic viability of the recycling process. Economy of scale is only possible when scrap is collected from more than one countries. On the other hand, the extraction processes have a high cost that is only justified when extracting significant quantities of expensive critical metals such as gold or the platinum group metals (PGMs).

Another aspect that hinders for further exploitation of critical metals is the existing legislation. At an EU level and at a national level in the Nordic countries, existing legislation with binding recycling targets refers to quantitative goals for recycling. In this way, bulky materials such as the mainstream metals become more important in recycling processes, as these can deliver much higher recycling quantities compared with the critical metals. 
Lastly, the fragmented data collection around the arisings and presence of critical metals in specific product groups, as this report has demonstrated, discourages policy makers from delivering qualified advice for policy interventions. A proper data collection system would help the planning and monitoring of new initiatives.

\subsubsection{Policy recommendations}

Ideas for effective policy recommendations can be developed on the basis of removing the barriers that hinder the increase in critical metals' recycling.

- Provide incentives for critical metals-rich product groups collection.

Legislation currently addresses WEEE as a uniform waste stream. However, if product groups with high concentrations of critical metals were provided with an incentive for separate collection, the smelters would benefit from both the economic aspects and the simpler processing of such a sub-stream. Higher concentrations of critical metals increase the value of the waste and the processing of the scrap is easier with fewer unwanted materials present.

- mphasise the qualitative aspects of recycling.

The environmental and economic importance of critical metals recycling is not addressed by existing policy measures that focus on recycled quantities, without differentiating between materials with high or low environmental and economic benefits. New policy measures that address these aspects would lead to a higher environmental and economic gain from recycling, bringing critical metals to the forefront.

- Standardise and target critical metals recycling.

Policy measures providing guidance on critical metals recycling processes, recommending best practice and highlighting the technical aspects of recycling, would offer recyclers a clear incentive for implementing better recycling techniques for WEEE in general and critical metals in particular. On the other hand, specific recycling targets for recycling of critical metals is a very strong incentive, as proved historically, for increasing their recycling. 


\subsection{The Nordic region's role in global critical metals discussions}

In the near-future, increasing demand from emerging environmental technologies and importance for strategic sectors might create pressure on prices of critical raw materials, even in times when resource prices are not growing for other commodities in general. For example, the World Bank estimates that oil prices could fall by $27 \%$ in 2016, but metal prices are expected to shrink by only $10 \%$. Furthermore, the market of critical metals globally can be characterized as oligopolistic: only a few companies and countries compete as suppliers of primary metals.

On the other hand, the Nordic region is one of the most affluent parts of Europe, consuming a large amount of electronic products compared to its population (Eurostat, 2015b). ${ }^{8}$ Altogether, the Nordic region's consumption is around $7.7-9.9 \%$ of the EU28. ${ }^{9}$ As such, the region produces a significant amount of WEEE containing valuable critical metals. It is also important to note that the concentration of metals in escrap is relatively predictable and can be compared to higher ore grades in geological deposits.

As such, installing additional recycling capacities in the Nordic countries could contribute to securing supplies, and partially satisfy the region's demand for these metals. However, there is insufficient data on annual use of these metals by the local industries to estimate how much of the local demand that metals recovered from waste could contribute. The criticality of these metals, to strategically important sectors including certain environmental technologies in which the Nordic region is a global leader, might alone justify building local recycling capacities.

Economy of scale is crucial, due to the small amounts of metals available in individual e-waste items, therefore only one or very few recycling installations would suffice: end-processing of WEEE is a globalised service and there are only few facilities in Europe. Umicore in Belgium recovers precious metals in an integrated smelter. Aurubis, Germany and Boliden, Sweden are copper smelters, which recover precious metals (Bakas et al, 2014). Yet, for example, the combined capacity of Boliden's e-scrap smelters is 125,000 tonnes (Boliden, 2016), so the combined amount of WEEE produced in the Nordic countries could potentially allow for the establishment of other installations.

${ }^{8}$ EEE put on market, $\mathrm{kg} /$ capita.

${ }_{9}$ Over the period of 2011-2013. 



\section{References}

Bakas I., Fischer C., Haselsteiner S., McKinnon D., Milios L., Harding A., Kosmol J., Plepys A., Tojo N., Wilts H., Wittmer D., 2014. Present and potential future recycling of critical metals in WEEE. CRI, 2014

BatteryUniversity (2009). Global Battery Markets, from: http://batteryuniversity.com/learn/article/global_battery_markets

Bigum, M., Brogaard, L., \& Christensen, T. H. (2012). Metal recovery from high-grade WEEE: a life cycle assessment. Journal of hazardous materials,207, 8-14.

Boliden (2014a), Annual Report 2014, Retrieved 14th January 2016, from: http://www.boliden.com/Documents/Press/Publications/Boliden_ar14_2015-0317_ENG.pdf

Boliden (2014b), GRI Report 2014, Retrieved 14th January 2016, from http://www.boliden.com/Documents/Press/Publications/GRI-14_eng_webb_pdf

Boliden (2016). Recycling of electronic scrap. Website information, from: http://www.boliden.com/Operations/Smelters/E-scrap-project/

Böni. H.; Widmer, R.(2011). Disposal of Flat Panel Display Monitors in Switzerland. EMPA, St. Gallen.

Buchert, M., Manhart, M., Bleher, D., Pingel, D. (2012). Recycling critical raw materials from waste electronic equipment. Oeko-Institut.

Chancerel, P., Rotter, V R., Ueberschaar, M., Marwede, M., Nissen, N F., Lang, K-D., (2013). Data availability and the need for research to localize, quantify and recycle critical metals in information technology, telecommunication and consumer equipment Waste Management \& Research 31(10) Supplement 3-16.

Cuchinella, F., D’Adamo, I., Lenny Koh, S.C, Rosa, P. (2015). RecyclingofWEEEs:An economic assessment of present and futuree-waste streams RenewableandSustainableEnergyReviews51(2015)263-272.

Espinoza Tercero, L A (2012). The contribution of recycling to the supply of metals and minerals. POLINARES working paper n. 20.

EC (2014). Directive 2012/19/EU of the European Parliament and of the Council of 4 July 2012 on waste electrical and electronic equipment (WEEE) Text with EEA relevance, from: http://eur-lex.europa.eu/legalcontent/EN/TXT/?uri=CELEX:32012L0019

Eurostat (2015a). Eurostat Prodcom database. Data extracted December 2015, from: http://ec.europa.eu/eurostat/web/prodcom/data/database

Eurostat (2015b). Waste statistics - electrical and electronic equipment, from: http://ec.europa.eu/eurostat/statistics-explained/index.php/Waste_statistics__electrical_and_electronic_equipment\#Electrical_and_electronic_equipment_put_on _the_market_by_country

Fox-Davies (2013). The Lithium market. http://www.globalstrategicmetalsnl.com/ _content/documents/405.pdf

Hagelüken, C.; Buchert, M.: The mine above ground - opportunities \& challenges to recover scarce and valuable metals from EOL electronic devices. Presentation at the IERC, Salzburg, 17.01.2008. 
Hagelüken, C., and Corti, W C., (2010). Recycling of gold from electronics: Costeffective use through 'Design for Recycling. Gold Bulletin. Volume 43, No 3, 2010.

Norgate, T., \& Haque, N. (2012). Using life cycle assessment to evaluate some environmental impacts of gold production. Journal of Cleaner Production, 29, 53-63.

Nuss, P., \& Eckelman, M. J. (2014). Life cycle assessment of metals: A scientific synthesis. PLOS One, DOI: 10.1371/journal.pone.0101298

Råvarumarknaden (2012). http://ravarumarknaden.se/en-kort-introduktion-tillravarumarknaden/

TemaNord (2009). Method to measure the amount of WEEE generated: Report to Nordic council's subgroup on EEE waste, from: http://norden.divaportal.org/smash/record.jsf?pid=diva2\%3A701677\&dswid=3780

UN (2015). UN comtrade database. Data extracted December 2015, from: http://comtrade.un.org/

UNEP (2013). Metal Recycling: Opportunities, Limits, Infrastructure, A Report of the Working Group on the Global Metal Flows to the International Resource Panel. Reuter, M. A.; Hudson, C.; van Schaik, A.; Heiskanen, K.; Meskers, C.; Hagelüken, C. UNEP (2011). Recycling rates of metals - A Status Report. A Report of the Working Group on the Global Metal Flows to the International Resource Panel. Graedel, T.E., Allwood, J., Birat, J-P., Reck, B.K., Sible, S.F., Sonnemann, G., Buchert, M., Hagelüken, C.

UNEP (2009). Critical metals for future sustainable technologies and their recycling potential. Sustainable Innovation and Technology Transfer Industrial Sector Studies. Buchert, M., Schüler, D., Bleher, D.

Umicore (2015). www.umicore.com.

U.S. Geological Survey (2016). Mineral commodity summaries 2016: U.S. Geological Survey, 202 p., http://dx.doi.org/10.3133/70140094

Van Maele, P (2016). Personal communication with Philippe Van Maele, Department Head - Sales \& Customer Service. Umicore Precious Metals Refining.

Van Beukering, P., Kuik, O., Oosterhuis, F., (2014). The Economics of Recycling. In: Handbook of Recycling. State-of-the-art for practioners, analysts, and scientists.

Vats M.C., Singh, S.K (2015). Assessment of gold and silver in assorted mobile phone printed circuit boards (PCBs). Waste management.

World Bank Group (2016). Commodity Markets Outlook, January.

World Bank, Washington, DC. License: Creative Commons Attribution CC BY 3.0 IGO. Yamane, L H., Tavares de Moraes, V., Crocce Romano Espinosa, D., Soares Tenório, J. A. (2011). Recycling of WEEE: Characterization of spent printed circuit boards from mobile phones and computers. Waste Management 31 (2011) 2553-2558. 


\section{Dansk Sammenfatning}

Metaller karakteriseres som kritiske, når deres leveringshastighed er lav sammenlignet med en stigende efterspørgsel. Yderligere elementer, der gør dem kritiske, er metallernes lave forekomst på kloden, lave genanvendelsesrater og muligheder for substitution samt deres betydning for specifikke formål, for eksempel militært udstyr og hi-tech produkter.

Brugen af kritiske metaller er udbredt i elektroniske produkter, og når disse produkter kasseres, indgår metallerne i de enkelte landes WEEE håndteringssystemer. Der har imidlertid været tradition for at det politiske fokus for genanvendelse af WEEE har været på den genanvendte mængde. WEEE håndteringssystemerne er således organiseret med henblik på at maksimere de genvundne mængder, hvorved materialer, der kun figurerer i små mænger men har en potentielt høj økonomisk og miljømæssig værdi, er blevet overset.

Dette projekt har til formål at undersøge, hvad der sker i affaldsstadiet med 11 kritiske metaller, der forefindes i fem udvalgte elektroniske produktgrupper, som nedenstående tabel illustrerer.

Table 24: Kritiske metaller

$\begin{array}{lccrrr}\text { Kritisk metal } & \text { Mobiltelefoner } & \text { PC'er } & \text { Fladskærm-TV } & \begin{array}{r}\text { Bærbare og } \\ \text { tablets }\end{array} & \begin{array}{r}\text { Genopladelige } \\ \text { batterier }\end{array} \\ \begin{array}{l}\text { Kobolt, Co* } \\ \text { Indium, In }\end{array} & + & & + & & + \\ \text { Lithium, Li* } & + & + & + & + & + \\ \text { Sølv, Ag } & + & + & + & + & + \\ \text { Tantal, Ta } & + & + & + & + & + \\ \text { Wolfram, W } & + & + & + & + & + \\ \text { Guld, Au } & + & + & + & + & + \\ \text { Beryllium, Be } & + & + & + & +\end{array}$

For at kunne vurdere genanvendelsespotentialet i disse metaller, er affaldsmængderne fra hvert af de udvalgte produktgrupper blevet kombineret med information om indholdet af kritiske metaller for hvert af de nordiske lande. Affaldsmængderne er estimeret ud fra salgsdata multipliceret med produktets gennemsnitlige levetid, mens metalindholdet baserer sig på en gennemgang at den seneste, relevante 
litteratur. Efter estimering af genanvendelsespotentialet, er der benyttet tilgængelige litteraturdata til beregning af de miljømæssige og $ø$ konomiske fordele ved genanvendelse af disse metaller sammenlignet med nyudvinding. Der er brugt livscyklusdata til estimering af de miljømæssige påvirkninger fra genanvendelsesoperationer (direkte emissioner) og for udvindingsprocesser for råmaterialer (undgåede emissioner). Den økonomiske værdi af genvundne metaller er antaget til at være den samme som for råmaterialer, da genanvendelse ikke medfører en nedgang i kvaliteten for de kritiske metaller.

Resultaterne af denne undersøgelse er afslørende i forhold til det meget høje potentiale, der er gemt i kasseret elektronisk udstyr i den nordiske region. Hvad angår affaldsmængder, så tegner kobolt og lithium sig for den højeste mængde, grundet deres høje tilstedeværelse i batterier, fulgt af guld og sølv. De miljømæssige og økonomiske fordele domineres af guld, der let tilskrives de højeste besparelser. Ved genanvendelse af de kritiske metaller i de udvalgte produktgrupper i alle nordiske lande er de potentielle besparelser på global opvarmning ca. 500.000 tons $\mathrm{CO}_{2^{-}}$ækvivalenter årligt for perioden 2015-2020. Den økonomiske værdi af metallerne i de udvalgte produktgrupper når op på 1,6 milliarder Euro, næsten udelukkende på grund af den høje værdi og mængden af guld.

Eftersom der er et stort økonomisk og miljømæssigt potentiale til udnyttelse gennem øget genanvendelse af kritiske metaller, er det nødvendigt at de nordiske lande griber til handling. Politiske anbefalinger kunne omfatte:

- Incitamenter til øget indsamling af kasserede produkter med højt indhold af kritiske metaller.

- Øget fokusering på de kvalitative aspekter ved genanvendelse og mindre fokusering på mængder alene.

- Standardisering og målrettet genanvendelse af selve de kritiske metaller. 


\section{norden}

Nordic Council of Ministers

Ved Stranden 18

DK-1061 Copenhagen K

www.norden.org

\section{Critical metals in discarded electronics}

Recycling of waste from electrical and electronic equipment (WEEE) traditionally focuses on large quantities of waste materials such as plastics. However, some product groups in the WEEE contain hidden treasures in the form of critical metals.

This project assesses the critical metals' waste handling as part of five selected product groups, in the Nordic region. The environmental and economic benefits from the recycling of these metals currently and in the near future is quite substantial, mainly due to the presence of significant quantities of gold in the selected products.

In order to contribute further to the circular economy concept, the Nordic countries should pay attention not only to quantitative but also to qualitative aspects of recycling, in order to capture recyclable materials that, although in small quantities, their recycling brings a high economic and environmental value.

TemaNord 2016:526

ISBN 978-92-893-4569-9 (PRINT)

ISBN 978-92-893-4570-5 (PDF)

ISBN 978-92-893-4571-2 (EPUB)

ISSN 0908-6692

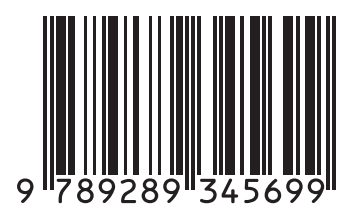

